\title{
Optikai kábel és regionális fejlesztés
}

A fejlett országokat pókhálóként beszövő rézhuzalok 100 éves története után most üvegszál-évtizedek következnek? E pusztán technikainak tűnő kérdés világszerte jelentős indulatokat ébreszt: részint mert a GEF-től az emberi kapcsolatok rendszerének radikális változását várják, részint mert a hagyományos telekommunikációs cégek csődjét prognosztizálják. A cikk e kényes pontokon túl is vizsgálja az új technika bevezetésének társadalmi előfeltételeit és messzire ható következményeit.

\section{Szerzői információ:}

Vietórisz Tamás

A New York-i Egyetem Közgazdaságtudományi Karának és Társadalomkutató Intézetének nyugalmazott tanára, város- és regionális tervezésből (globális piac, fenntartható fejlődés) vendégelőadó a New York-i Cornell és Columbia Egyetemeken. Egyetemi tanulmányait Budapesten, Bázelben és Zürichben végezte. Vegyészmérnöki diplomája után a Bostoni Mû́szaki Egyetemen közgazdaságtudományból doktorált. Munkáiban arra hívja fel a figyelmet, hogy a növekvố technikai / gazdasági lehetôségek és a társadalmi döntéshozás (beleértve a társadalmi egyenlôséget és a környezetet is) között szoros összefüggés van. Jelenleg az alábbi területeken végez kutatásokat: a globális vállalati hálózattal összefüggő kétes munkaeró-piaci viszonyok; a fejlesztés kulturális, pszichológiai és technikai tényezôi közti kölcsönhatás, vidék- és várostervezés Európában, különös tekintettel Magyarországra.

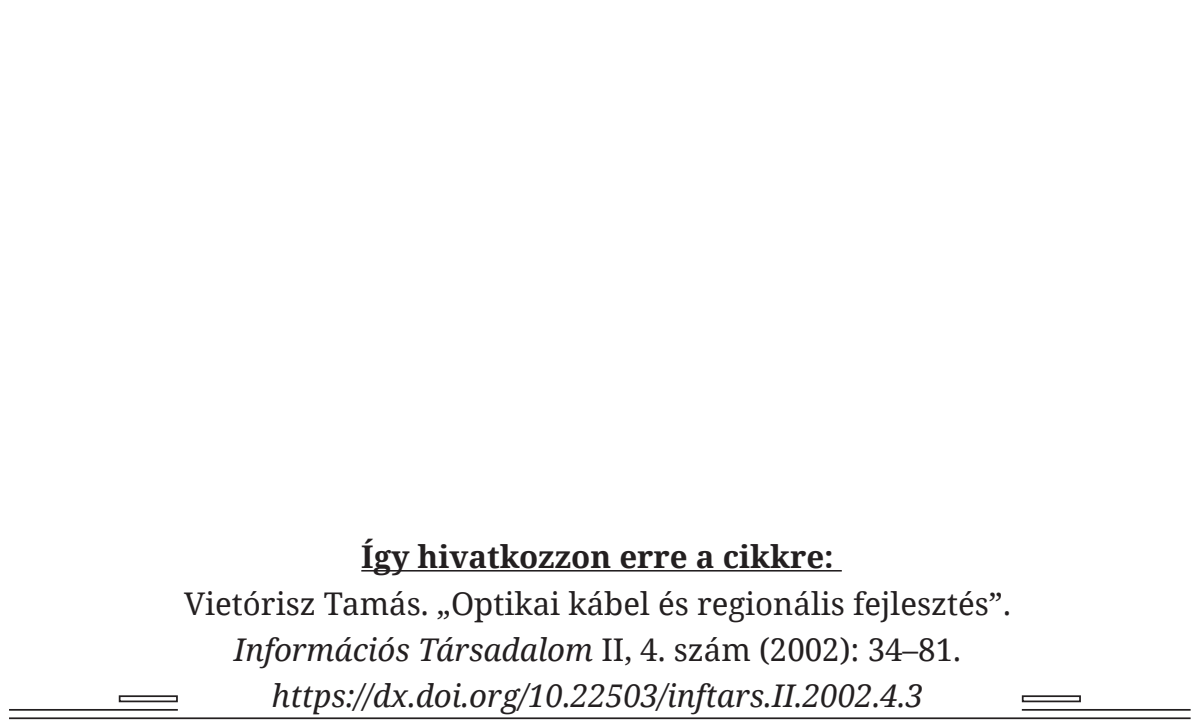

Vietórisz Tamás. „Optikai kábel és regionális fejlesztés”.

A folyóiratban közölt müvek

a Creative Commons Nevezd meg! - Ne add el! - Így add tovább! 4.0

Nemzetközi Licenc feltételeinek megfelelöen használhatók. 
Vietórisz Tam á s ${ }^{1}$

\section{Optikai kábel és regionális fejlesztés ${ }^{2}$}

\section{A szélessávú optikai hálózatok területén történt legújabb változások}

Kevesebb mint egy éve, amikor az Institute of Electrical and Electronic Engineers (IEEE-USA) egyesületnek Szélessávú Hálózatok 2002 júniusi Múhelye még a tervezés stádiumában volt, a vele együttmúködő Cornell munkacsoport azon gondolkodott, hogy mik is lehetnének majd az új Múhely elérhetô eredményei. Az akkori a megbeszélések elsődlegesen az optikai gigabit sebességű Ethernettel (GEF) kapcsolatos néhány, széles körben elterjedt téves felfogás eloszlatására összpontosítottak (Ethernet: a legelterjedtebb helyi hálózati rendszer, melyet az IEEE 802.3 számú szabványa definiál). Ez a technológia akkor a gazdaságosság szempontjából legvonzóbb lehetôség volt - és még ma is az - a gigabites sebességú, végponttól végpontig üvegszálon vezetett szélessávú Internet hálózatok („G-sáv”) tömeges bevezetésére. ${ }^{3}$

Regionális szempontból kulcskérdésnek számított, hogy a helyi fejlődést mennyire tarthatják vissza ezek a téves felfogások és hogy egy-egy terület - fôként egy elmaradottabb térség - mennyi előnyt nyerhet azzal, hogy csatlakozik a GEF telepítésének előôrséhez. Akkor még kevés remény volt arra, hogy a Múhely a téves felfogások eloszlatásán túl a GEF telepítésével is foglalkozzon. A legfóbb akadályt az képezte, hogy a DSL (digitális előfizetôi vonal) és a modemmel kapcsolt szélessávú kábelhálózat, amelyek a „K-sávban” (kilobit) és elméletileg legfeljebb az alsó „M-sávban” (megabit) továbbítják az adatokat, elvonták a GEF-ról a nyilvánosság figyelmét. Így a GEF széleskörű bevezetése mellett érvelni a telekommunikációs cégek és a kábeltársaságok gazdasági és politikai túlsúlyával szemben nem tûnt reális célnak.

Egy év elteltével azonban a helyzet jelentősen megváltozott. A GEF időközben, az uralkodó téves felfogásokat megcáfolva, nemcsak a legjobb szakértôk értékeléseiben és irányelvi javaslataiban mutatott előrelépést, hanem magának az optikai üvegszál vonalaknak a telepítésében is. Mi több, a legújabb keletú adatok szerint az átláthatatlan könyvelés kulisszái mögött a nagyobb telekommunikációs cégek és az egész szektor anyagi helyzete - úgy az USA-ban, mint Európában - olyannyira megromlott, hogy az már komoly aggodalmakat keltett pénzügyi körökben. A telekommunikációs cégek által a GEF ellen felhasználható gazdasági tartalékok szemmel láthatólag csökkennek, és már csak az a kérdéses, hogy kedvező szabályozó kormányrendelkezéseknek és az elavult szélessávú technológiák anyagi megsegítésének kiharcolásával mennyi ideig dacolhatnak még a GEF-fel a politika küzdôterén. Ilyen téren már mind az USA-ban, mind Európában történtek fontos lépések. Ezek a problémák a késóbbiekben kerülnek megvitatásra. 


\section{Regionális kihatások}

Jelen elemzés tárgya a végponttól végpontig terjedó optikai üvegszálas gigabites Ethernet (GEF) hatása a regionális fejlödésre, fóként Észak-Amerikára és Európára összpontositva, ahol már létezik az optikai kábeles információs szupers:tráda, de ez a végső felhasะnálóktól nem meszsze megáll. Különös figyelmet érdemel az optikai üvegszál vezeték, mint olyan eszköz, amely fontos szerepet tölthet be a visszamaradott területek fejlesstésében.

Az elemzés feltételezi, hogy a végponttól végpontig terjedő üvegszálra történő átállás hosszú távon elkerülhetetlen. Ugyanakkor elismeri azt is, hogy az egyes területek számára kulcsfontosságú, hogy az átállás lebonyolítására vonatkozó irányelveket úgy fogalmazzák meg, hogy a helyi fejlődés céljait a legjobban szolgálják.

A mai globalizálódó tudásgazdaságban a GEF-re mint igen fontos fejlesztési eszközre való átállás hatékony irányítása, a társadalmi kommunikáció két különböző infrastruktúrájának kölcsönhatásától függ. Ezek az optikai üvegszál és más hálózatok „kemény” (vö. hardware) technikai infrastruktúrája (beleértve nyomvonalaikat, oszlopaikat, csöveiket, és egyéb tartószerkezeteiket is), valamint a történelmi alapú, lassan kifejlődő értékek, kapcsolatok és szokások „puha” (vö. software) kulturális infrastruktúrája.

\section{SZÉLESSÁVÚ OPTIKAI HÁLÓZATOK}

\section{A közelgő forradalom}

A gazdaságos GEF technológia lehetôvé teszi, hogy a gigabit sebességű optikai üvegszálas Internetet ne csak a hosszú évek óta használt nagytávolságú telekommunikációs vonalakon alkalmazzuk. Használatával az információt végponttól végpontig, az átvitel elsố és utolsó kilométereit is magába foglalva lehet rendkívül gyorsan továbbítani. Ez most az optikai szélessávú hálózatok forradalma során kerül bevezetésre, annál az egyszerú, mindazonáltal mindennél fontosabb oknál fogva, hogy a helyi hozzáférési vonalak összesített hossza - ezeken az első és utolsó kilométereken - nagyságrendekkel haladja meg a nagytávolságú vonalak összesített hosszát. Ezért a nagytávolságú vonalak rézkábelekról optikai kábelekre való cseréjének a költsége jelentéktelen volt ahhoz képest, amennyibe az kerül, hogy a helyi hozzáférési vonalak összességét lecseréljük. Természetesen ez egyelôre csak az iparilag valamennyire fejlett társadalmak számára elérhetố, s ott is fokozatosan, de hosszabb távon az elmaradott térségek és végül a Harmadik Világ területei is meg tudják ezt majd valósítani.

Az optikai szélessávú hálózatoknak óriási fölényük van a hagyományos telekommunikációval szemben. Egy gigabites GEF kapcsolat sávszélessége tizenötezerszerese az átlagos telefonvonalénak és ezerszerese a DSL-nek vagy a koaxiális TV kábelének ${ }^{4}$. Ez az előny egy adott hullámhosszú fényre igaz. Sốt, minden szál képes arra, hogy egyidejúleg több különbözố színú, azaz különbözô hullámhosszú fényt továbbítson anélkül, hogy köztük kölcsönös interferencia vagy áthatás lépne fel, ami telefonvonalaknál gyakori probléma. Ma a két-három hullámhossz használata széles körben elterjedt az optikai szál végponttól végpontig terjedő alkalmazásainál, míg néhány tucat hullámhossz gazdaságos a hosszú távú gerincvezetékeknél. Laboratóriumokban már ezernél több hullámhosszal is végeztek sikeres kísérleteket. 
Ezen felül a következő évtizedekben várható, hogy ez a fölény körülbelül három nagyságrenddel megnôjjön, s hogy így az optikai szélessávú hálózatok terabit nagyságrendbe kerüljenek. Ez azért lehetséges, mivel az optikai szál a technológiai életciklusának még csak az elején jár, amíg a réz már a végén tart - a DSL utóvédharcával együtt is. Ugyanez a helyzet a koaxiális kábellel.

Az optikai üvegszál vezetékkel lehetségesen elérhetố sávszélesség a jelenleg gazdaságos technológiákkal kihasznált sávszélességekkel szemben olyan hatalmas, hogy a földbe fektetett vagy a póznákon kihúzott vonalak évtizedekre biztos jövônek néznek elébe. A sávszélesség egyszerüen tovább növelhetô úgy, hogy a szálak végéhez fejlettebb technológiájú berendezéseket telepítünk.

Az alacsony költségű, készen kapható, 1Gigabit szabványú berendezéseket használó - ám a gyakorlatban ennél valamivel gyorsabban múködő - optikai Ethernet LAN-ok (local area networks = helyi hálózatok) most már nem csak épületegyütteseket köthetnek össze, hanem nagyvárosi vagy városon kívüli területeket is. A $10 \mathrm{~Gb}$ es LAN szabványt az IEEE-USA tavaly nyáron véglegesítette. Természetesen ennek a berendezésnek a költségei ma még magasak, mintegy 30-40-szeresei az 1 Gbit-es szabványúénak, de ahogy a 10 Gb-es változat elterjed, úgy a költségek is rohamosan csökkenni fognak.

Mivel az optikai és a hagyományos telekommunikációs technológiák ennyire egyenlőtlen viszonyban állnak egymással, Schumpeter kreatív pusztításának forradal$\mathrm{ma}^{5}$ egyre gyorsabbá válik a telekommunikáció világában. Amint ez a forradalom fokozatosan előrehalad, nagy mennyiségú hang-, videó- valamint adatinformáción, és fóképp a számítógépek kommunikációjából származó óriási adatmennyiség átvitelére legtöbb esetben az optikai szálak földi vonalait fogja használni . Ezeket a földi vonalakat drótnélküli átvitelek fogják kiegészíteni ott, ahol a mobilitás igénye erôsebb a sávszélesség igényénél, mint például a mobiltelefonok esetében, vagy ahol a nagy sávszélesség nagyon kis távolságokon lehetséges, mint például beltéri, vagy minimális méretű kültéri használatú, hordozható számítógépeket ellátó drótnélküli internetes kapcsolódási csomópontok esetében ${ }^{8}$. A drótnélküli kapcsolat akkor is hasznos, ha a terepviszonyok nem megfelelőek, vagy a végpontok alacsony sűrűsége miatt a földi vonalak lefektetése túl drága. A legrövidebb, legfeljebb méterekben mérhetố távolságok esetében, például épületekben vagy épületek között, a sávszélesség alig csökken, ha drótnélküli kapcsolattal vagy netalán rézvezetéken keresztül történik az információátvitel.

A földi vonalak különbözô lehetséges hálószerkezetei, mint például az üvegszálra, múanyag szálra ${ }^{9}$ vagy fotonkristályra építve ${ }^{10}$, még a színfalak mögött várakoznak. A Megabit-sebességű drótnélküli kapcsolat gyakran bizonyul kívánatos választási lehetőségnek áthidaló technológiaként, amíg a Gigabit-sebességű földi vonalak elkészülnek. Ugyanez történik a napi fốbb weboldalak múholdas szétosztásánál is. ${ }^{11}$

A Gigabit-sávszélességú hálózat egyik korai megvalósulása volt a kanadai CA*net3 projekt, amely a főbb egyetemeket és kutatóközpontokat kötötte össze ${ }^{12}$. A CA*net3, amely 1999-ben áthidalta Kanada keleti és nyugati tengerpartját, volt a világ elsố országos szintû optikai $\mathrm{K}+\mathrm{F}(\mathrm{R} \& \mathrm{D}$ research and development $=$ kutató és fejlesztő) hálózata, amit azóta is igyekeznek követni szerte a világon ${ }^{13}$. A hálózat tervezôi jelentôs megtakarításokat értek el azzal, hogy kizárólag az internetes adatátvitelre összpontosítottak ahelyett, hogy az Internetet a hagyományos telefonhálózati tervezet által vitték volna át. Ez lehetővé tette, hogy kiküszöböljék a hagyományos 
hálózatok bonyolultságával ${ }^{14}$ együttjáró számos problémát, miközben pénzt takarítottak meg és a szolgáltatás minôsége sem csökkent. Bill St. Arnaud, az Advanced Networks of Canarie, Inc. vezetôje szerint:

Amikor a CA*net3 hálózatát telepítettük (DWDM-en és sötét szálas optikai kábelen) meglepetve tapasztaltuk, hogy milyen olcsó is volt az optikai szál alkalmazása iskolák, egyetemek és kórházak esetében. Nagyságrendekkel került kevesebbe, mint amit a telekommunikációs cégek előreláttak. (...) Úgy találtuk, hogy egy iskolánál az optikai szálas csatlakozás kiépítése - országos szintű fejlesztés során - 25000 dollárba kerül. Ezt tôlünk függetlenül más könyvvizsgáló és tanácsadó cég is igazolta. ${ }^{15}$

$\mathrm{Az}$ adatokat az internetes átvitel során korlátozott hosszúságú „csomagokra” bontott bitfolyamokként kezelik. Ezek a csomagok külön és egymástól független útvonalakon jutnak el a hálózatok vonalain keresztül a célállomáshoz, ahol újra összerendezik őket. Helyi hálózatoknál előforduló torlódás miatt esetenként elveszhetnek csomagok. Ilyen esetekben a célállomásnál lévő összeállító szoftver üzenetet küld oda, ahonnan a csomag érkezett, hogy a hiányzó csomag(ok)at újra elküldjék. ${ }^{16}$ Ez idószakos fennakadásokat okoz a fogadónál. Azonban hamarosan észrevették, hogy a Gigabit-sávszélességú Interneten keresztül küldött digitalizált hang- vagy videóanyag minôsége felveszi a versenyt a telefonvonalon hagyományos úton átvitt hang minőségével, mert a gigabites adatátviteli sebesség mellett a fennakadások és akadozások jóval az érzékelési küszöb alatt vannak a fogadónál. További költségcsökkentést értek el azáltal, hogy az egyszerúsített telefonos technológiáról a GEF-re tértek át, így a beruházások összességükben 8-10-szer kerültek kevesebbe, mintha a telekommunikációs cégek hagyományos technológiáját használták volna. ${ }^{17}$

Jelenleg - a CA*net3-tól és az azt követô Canet-4-tôl eltekintve ${ }^{18}$ - a GEF-et használó Gigabit-sebességú Internet fốleg a korlátozott méretû hálózatoknál terjedt el. Ezek mérete a néhány egyetemi központban és iparvállalatnál használt helyi hálózatoktól (LAN-ok) a nagyobb kiterjedésû, több tíz kilométer kiterjedésû hálózatokig - iskolarendszerek, közigazgatási területek és városok - változik. Valamivel kiterjedtebb hálózatok létesültek a kanadai Alberta és Quebec tartományokban, amelyek fóként egyetemeket, iskolákat és kórházakat kötnek össze, valamint a fóbb csomópontoknál csatlakoznak a nemzeti hálózathoz. ${ }^{19}$ Ilyen kiterjedt hálózatot találunk Svédországban is, fốleg Stockholm környékén. ${ }^{20}$

A kezdetek óta a GEF forradalma fokozatosan, alig észrevehetően terjed, egyre nagyobb eredményeket érve el. Egyre inkább tekint olyan ambiciózus tervek felé, mint például a házig érô üvegszál (FTTH = fiber to the home) az USA-ban, ami megindult Spokane, WA városában és a környező Grant County területén, ${ }^{21}$ valamint Palo Alto, CA városában. ${ }^{22}$

Nagy tétek forognak kockán a GEF elốrenyomulásával. A szélessávú optikai hálózatok forradalma azzal fenyeget, hogy a telefonokhoz használt rézvezetékek évszázados, vagy a televízióadások közvetítéséshez használt koaxiális kábelek évtizedes befektetései elavulttá válnak. Egy, vagy legfeljebb két évtizeden belül ezeknek a befektetéseknek a nagy része fokozatosan értékét veszti, azoknak a helyeknek a kivételével, ahol a magukat körülsáncoló telefon- vagy kábeltársaságok monopóliumaikkal vagy politikai befolyásukkal fel tudják tartóztatni a technológiai fejlődést.

Ám a fejlôdés feltartóztatására irányuló erôfeszítések nem sikerülhetnek mindenhol a világon. Ahol a GEF egyre jobban tért tud hódítani, ott a hagyományos réz- 
és koaxiális kábel befektetéseket fel fogják váltani a végponttól végpontig terjedő optikai szálas vonalak. Ez megnyitja az utat egy globálisan hozzáférhetô, tömeges Gigabit-sávszélességû Internet-alapú adat-, hang-és videó-telekommunikációs átvitel számára. Ezzel szemben azokban az országokban, ahol a telekommunikációs cégek és a kábeltársaságok sikeresen lépnek fel érdekeik védelmében a GEF terjedésének viszszaszorításáért, akár azt is eredményezheti, hogy az adott ország nemzetközi versenyképessége a jövőben katasztrofálisan csökkenni fog.

\section{Téves felfogások és tények a GEF-fel kapcsolatban ${ }^{23}$}

A következókben, hogy megvizsgáljuk a GEF-nek a regionális fejlődésre gyakorolt hatását, néhány széles körben elterjedt téves felfogás és az azokat cáfoló tények kerülnek megvitatásra.

"A végponttól végpontig terjedó optikai szál alapú Internet, föleg ha otthonokba kötik be, túl sokba kerïl a felhassnáló számára, még Ethernettel (GEF) is."

Az alapvetố tévedés itt az, hogy az optikai szál-alapú Internet a DSL-lel vagy a kábel alapú szélessávú hálózatokkal versenyez. Igazából viszont a verseny itt a szélessávú hálózatokkal, a telefonnal és a kábellel szemben együttesen zajlik, azzal a céllal, hogy az összes alkalmazás egy üvegszálas megoldásra történő együttes áttelepítési költségeit csökkentse. Emellett arra törekszik, hogy növelje a sebességet, minôséget és a versenyképes választást, szem előtt tartva a Gigabites sebességú Internettel elérhetố kiváló szolgáltatási kínálatokat.

A fent említettek mellett azonban nem szabad alábecsülni két fontos szempontot. Az elsố az, hogy a GEF telepítése idôt és tetemes anyagi beruházást igényel. Ezért még az iparilag fejlett országok is eleinte azzal kezdik a telepítést, hogy nyilvános hálózatokkal kötnek össze egyetemeket, iskolákat, kórházakat és más közszolgálati egységeket, vagy jelentôsebb vállalatok belsô hálózatait. Az optikai szálat csak akkor vezetik be az otthonokba, ha az előbb említett hálózatokat már kiépítették az adott régióban. A második probléma az, hogy az eddig említett megfontolások még nagyobb súllyal esnek latba azokon az elmaradottabb területeken, ahol kevesebb erôforrás található. Ezért az áttérés telefonvonalról vagy kábelhálózatokról a mindenütt jelenlévő GEF-re alapos megfontolást és tervezést igényel. Erre még később részletesen szó lesz.

\section{„A GEF sávszélessége nem igazán szülkséges az otthonokban.”}

Ha már helyben van a GEF, a sávszélesség iránti igény ugrásszerúen megnô. A beágyazott, koncessziós (incumbent) szolgáltatók tétlensége azzal indokolható, hogy a felhasználók nem akarják megfizetni azt a pluszköltséget, amely egy Gigabites sebesség otthonukba vezetését jelentené. Ezzel az ellenállással szemben, a GEF előnyei azokban a változásokban nyilvánulnak meg, amelyek akkor válnak lehetségessé, ha az optikai szélessávú hálózatok egy-egy területen széles körben elérhetővé válnak a telefon, kábel és az Internet-hozzáférés egyesített üvegszálas megoldásával. Ilyen alapon a szükséges befektetések amortizációs költségei havi 40 dollár körül lennének. ${ }^{24} \mathrm{Ez}$ nemcsak megvalósítható, hanem nagyon is vonzó lehetőség az amerikai, kanadai vagy nyugat-európai jövedelmeket tekintetbe véve. Hiszen a háztartások - eddig három különböző szolgáltatónak fizetett - költségei jelentősen csökkennének. 
A következô példa jól illusztrálja, mi történik a közszférában, ha egyszer az optikai szélessávú hálózatok elérhetővé válnak. A Broome-Tioga iskolarendszer - amely New York állam északi részén saját tulajdonában üzemelteti az optikai szálakat - 1 Gbps-el kezdett, most 4 Gbps-es sebességet használ, és a jövőben tervezi a 8 Gbpses sebesség bevezetését. ${ }^{25} \mathrm{~A}$ háztartásokban jelenleg 0.1 Gbps-t lehet használni, de itt is hasonló növekedés prognosztizálható az újabb telepítéseket és az új szolgáltatói ajánlatok alapján. ${ }^{26}$ A Broome-Tiogai fejlesztések készen vásárolt nagyobb teljesítményú végberendezések telepítésével mentek végbe anélkül, hogy a már telepített optikai szálakat megbolygatták volna.

A 10 Gbps-es Ethernet (10GigE) technológiáját tavaly nyáron szabványosította az IEEE-USA és a berendezés már kereskedelmi forgalomban kapható. Ma még meglehetôsen drága, ám ára várhatón 3-5 éven belül a mai $1 \mathrm{GigE} \mathrm{technológia} \mathrm{árszintjére}$ csökken. Egyes mérnökök már olyan üzleti terveket is fontolgatnak, miszerint a 10 GigE végberendezkedések (transceiver) tömeggyártását is megkezdhetnék. ${ }^{27} \mathrm{~A}$ következô évtizedekben az igények növekedésével és a bővítés költségeinek csökkenésével a folyamatos bővülés elérheti a terabites tartományt is. Ebben a tekintetben az optikai szál az otthonok, iskolák vagy egyéb felhasználók számára legalább a következô húsz évben olyan szerepet játszhatna, mint amit a réz az elmúlt száz évben.

\section{"A GEF nem finanszirozható."}

Ez a téves felfogás a rendelkezésre álló finanszírozási alternatívákra vonatkozik,a lehetôségek ugyanis szélesebbek, mint a tốkepiac alternatívái. Ennek az az oka, hogy a tôkepiac számára nem érdekes az Internetet végponttól-végpontig vezetô optikai szál hálózat, mert ez a hagyományos szolgáltatásokat tömegcikké alakítja át és csak csekély hasznot ígér. ${ }^{28}$ Ezzel szemben, a GEF finanszírozási lehetôségei között szerepelnek a felhasználók telekommunikációs megtakarításai - az összekapcsolt iskolai rendszerekbe befektetett összeg például már néhány éven belül megtérülhet. ${ }^{29}$ Ezért minden régiónak vagy városnak alaposan át kell tanulmányoznia az olyan eseteket, amelyek a városok, lakóközösségek vagy nonprofit szervezetek üvegszálas optikai szálhasználatával vagy az alépítmény tulajdonjogával függnek össze. A végfelhasználók, közülük is leginkább az ingatlantulajdonosok, sokszor hajlandók az ingatlanfejlesztésekre kirótt adók növelését elfogadni, feltéve, hogy ezek csökkentik telekommunikációs kiadásaikat, mivel átlátják, hogy a magánvállalatok tôkeköltségei magasabbak, mint a közületi befektetések finanszírozási költségei a kötvénypiacon. ${ }^{30}$

\section{"A GEF az adofizetốk pénzét használja."}

Épp ellenkezőleg, a GEF pénzmegtakarítást hoz az adófizetőknek. A városi, megyei vagy tartományi önkormányzatok telekommunikációs költségvetési megtakarításai, hasonlóan az iskolakerületek megtakarításaihoz, amelyeket egy közületi GEF hálózat tesz lehetôvé, tipikus esetben néhány év alatt letörlesztik a hálózat befektetési költségeit, s utána nettó költségvetési megtakarítást eredményeznek. Emellett minden adófizetô polgár pénzt takaríthat meg azzal, hogy havonta nem kell többfajta számlát kifizetnie egy monopolizált, elavult, a telekommunikáció infrastruktúrájának integrálását meg nem engedő technológia miatt. Mi több, a társadalom számára a technológiai újítások kimaradása, amelyekért egy elavult hírközlési infrastruktúra felelôs, rendkívül drága, épp ezért igen nagy társadalmi haszon várható a bőséges sávszélességellátás új és kreatív módon történő kiaknázásától. Ez új munkalehetőségeket és több pénzt jelent a közösségeknek, és minden adófizetô elônyére válik. 


\section{„A GEF-be beruházott péns nem hoz has:not (nem várható $R O I=$ return on investment)."}

Ez a téves felfogás abból ered, hogy a ROI-t egy túlzottan szúk kereskedelmiberuházási szemszögből vizsgálják, amely nem szükségképpen helytálló, amikor a térségi fejlődésről van szó. Ezzel szemben helyes az a megállapítás, hogy amikor egy közösség számára maximalizálni kívánjuk a GEF nyújtotta lehetőségeket, akkor elegendôen bôséges GEF kapacitást kell teremtenünk ahhoz, hogy ennek a kapacitásnak a szúkösségi bérét (scarcity rent) kiküszöböljük, s ezáltal a sávszélesség használatának határköltségét (marginal cost), tehát annak szabad versenyre jellemzố piaci árát, nullára csökkentsük. Ez természetesen összeférhetetlen a magáncégek céljaival, amelyek a saját bevételeik növelésére, nem pedig a GEF-ból származó közösségi előnyök elérésére irányulnak. Mégis, az elôbbi nem jelenti a ROI hiányát, ha a beruházást egyéni magánfelhasználók kívánják létrehozni saját érdekükben, és nem egy kereskedelmi egység, amely csak nyereséget kíván elkönyvelni. Szintén nem jelenti a ROI hiányát, ha a beruházásról a döntést a településen élő magánfelhasználók érdekében a város vagy község hozza meg. Ez esetben hasonló lesz a helyzet ahhoz, mint amikor a város olyan infrastrukturális fejlesztésébe kezd, mint fóútvonalak, utcák vagy közvilágítás javítása vagy kiépítése, mert ezek szintén nem jelentenek bevételi forrást a magáncégeknek, de fontos közhasznú szereppel bírnak.

\section{„A GEF kijátssza a piaci eróket.”}

Ez csak akkor lenne igaz, ha a kívánt „piaci erők” kifejezés a monopolizált piacokat jellemző, megkérdőjelezhetô árstratégiával múködő erôkre vonatkoznék - amelyek semmiképp sem lehetnek egy ideális demokratikus piaci modell részei. Ezzel ellentétben, ha azokra az erőkre gondolunk, amelyek a szabad versennyel múködő piacokra jellemzôek, akkor éppen a GEF erôsíti meg dezeket az erôket, míg a telefonés kábeltévé-monopóliumok játsszák ki ôket. Az utóbbiak éppen azért szeretnék meggátolni a végpontokig kiépített optikai szál terjedését, mert az a szabadabb versenyt hozza magával az opcionális és magas értékű szolgáltatások terén.

\section{A telekommunikációs cégek a GEF ellen: fantom vagy valóság}

A legfő́bb téves felfogás, amely a helyi fejlődést visszatartja, a telekommunikációs cégekhez füződik.

„A beágyazott telekommunikációs cégek olyan erôsek, hogy szinte korlátlamul gátolhatják vagy késleltethetik a GEF telepitését."

Ez a téves felfogás különösen romboló hatású, mert leállítja az építő jellegú próbálkozásokat, változásokat. Ólomsúlyként nehezedik a visszamaradott területekre, mert e régiók számára - viszonylagos hátrányaik szemszögébốl nézve - mindenhatóknak tûnnek a beágyazott telekommunikációs cégek.

De az a kép, miszerint az ilyen cégek legyő́zhetetlen ellenfelek volnának, a jelen fejlemények fényében erôsen túlzottnak tûnik. Ebben a tekintetben fontos új információval szolgál a 2002. április-májusi Cook-jelentés, a Roxane Googin technológiai elemzővel készített interjú és több hozzászólás is. A telekommunikációs cégek vezetố üzletemberei, akik túlzott optimizmussal mértéktelenül sokat fektettek be a kötvényekkel finanszírozott, technikailag túlfinomított SONET-hálózatokba (Synchronous Optical NETwork: szinkron optikai hálózat), most szembe kell, hogy 
nézzenek a hagyományosan magas díjú beszédszolgáltatások folyamatos leépülésével, melyekre nagyban számítottak kötvény adósságaik visszafizetése érdekében. A többi szolgáltatásuk sokkal erôsebb versenynek kitett árú és ezért nem jelent komoly segítéget, a DSL mellesleg még külön tehertétel is lehet. Ezért a telekommunikációs cégek a következő három-négy-öt év során, esetleg hamarabb is, könnyen csődbe sodródhatnak. ${ }^{31}$ A Precursor Group egyik jelentése még élesebben azt állítja, hogy a tôzsdén jegyzett telekommunikációs cégeket, néhány kivételtôl eltekintve, rövid időn belül a csőd veszélye fenyegeti, s összefonódásaikkal - pénzügyi problémáik továbbadásával - az egész szektort a mélybe ránthatják. ${ }^{32}$

David Isenberg ${ }^{33}$ szerint a telekommunikációs cégek jelenlegi problémái a „telekommunikációs szektor általánosan kétes kilátásaiból fakadnak, amelyeket még súlyosbítanak az adósságok eltitkolása és egyéb nyilvánosságra került könyvelési trükkök, valamint az aránylag nem túl radikális technológiai változtatások (mint például mobiltelefonok használata a földi vonalak helyett, vagy az e-mail használata a telefonhívások helyett)." ${ }^{34}$ Ezért a kis számú újonnan kiépített optikai hálózat mindeddig csak másodlagos szerepet kap az aktuális problémák sorában. Hosszútávon mégis „a már kiépített hálózatok üzleti megfeneklése jelenti a kritikus tényezôt, mivel ezeket meghaladottá teszik a jelentősen olcsóbb, alapjaikban egyszerúbb hálózatok." ${ }^{35}$ Már egyre több tudományos és üzleti telephelyen (campus) cserélik le a régi rendszereket GEF-re és ez a folyamat az iskolörzeti és városi kiépítésekre is kiterjed.

A fent említett tények alapján reálisabbnak túnik az a megállapítás, hogy a telekommunikációs cégek roppant erôsek. A való helyzet az, hogy szélessávú hálózati megoldásukat, a DSL-t, a GEF sokkalta nagyobb sávszélessége kenterbe veri; a pénzügyi vonalon pedig sebzettek vagy megnyomorítottak. A GEF elleni szabályozási és politikai csatákban a kábeltelevíziós társaságokban szövetségesükre találnak, ám a kábel-TV társaságok gyenge szövetségesek a GEF-fel szemben. Egyrészt a kábelmodemeiknek ugyancsak korlátozott a sebességük ${ }^{36}$, másrészt a telefontársaságokhoz hasonlóan centralizált rendszerekkel múködnek, melyek kevéssé alkalmasak az Internet sûrû́n összekötött hálózatain az egyes pontok közötti forgalom lebonyolítására. Mindezeken felül a kábeltársaságok sem a pénzügyi erő fellegvárai - néhányan közülük, mint például az AOL/Time Warner, komoly anyagi gondokkal küszködnek.

Ezért a látszólag nagyarányú szabályozó és törvényhozói támogatás ellenére, amit a telekommunikációs cégek és a kábeltársaságok meg tudnak mozgatni céljaik érdekében - például a korlátolt teljesitöképességü DSL és kábelmodemek privilegizált telepitésére a GEF alapú optikai hálózatokkal szemben - ezek a cégek aligha tudják már hosszútárra, még kevésbbé belátható vég nélkül, tartani sáncaikat.

Épp ellenkezőleg: a telekommunikációs cégek megingott anyagi helyzete felveti a szektor összeomlásának lehetôségét még mielốtt a GEF fokozatos telepítése közel is érne a végéhez. Googin és Isenberg tartanak ettốl a lehetôségtôl. ${ }^{37}$ Kell is, hogy tartsanak, hiszen a regionális fejlődést erősen veszélyeztetné a telefonos rendszer túl korai összeomlása.

Ami az amerikai telekommunikációs cégeket fenyegetố anyagi veszélyeket illeti, az ugyanannyira, ha nem jobban érvényes a beágyazott európai telekommunikációs cégekre is. Ezek a vállalatok anyagilag túl vannak terhelve, méghozzá nemcsak a beszédhang átvitelre orientált hagyományos infrastruktúrájuk finanszírozásával, hanem még inkább annak a következményeivel, hogy a közelmúltban egészen irreális licitációs csatákba bocsátkoztak a következő-generációs drótnélküli telepítések frekvenciáinak le- 
kötésére. Ahogy az USA-ban, úgy Európában is a DSL és a kábel jelentik a sávszélesség fejlesztését ${ }^{38}$, míg a végponttól végpontig tartó optikai szál telepítése hiányzik a tervek közül, kivéve Svédországot és néhány kísérleti vállalkozással, Hollandiát is. Az Európai Bizottságnak az információs társadalomra vonatkozó jelenlegi akcióterve, mely a szélessávú hálózatok fejlesztését hangsúlyozza, az optikai hálózatok támogatását csak kutatói közösségekkel kapcsolatban említi. ${ }^{39} \mathrm{~A}$ jelentésben szereplô pénzügyi támogatások tervezete azt a benyomást kelti, hogy az csak egy gyengén álcázott eszköz a telekommunikációs cégek krízisének enyhítésére.

Ahogy a GEF-fel kapcsolatos téves felfogások sorra tisztázódnak és ahogy a szórványos, de megvalósított GEF-telepítések száma nő, a GEF-re való áttérés egyre nagyobb súlyt kap és egyre inkább elkerülhetetlen távlatot jelent a telekommunikációs üzletpolitikában. Az áttéréssel kapcsolatos problémákat a területi fejlesztések céljaival együtt tárgyaljuk. Ezeket a célokat a következó fejezet tekinti át.

\section{A TERÜLETI FEJLESZTÉS CÉLJAI}

\section{A célkitüzés}

A GEF-rôl és a hagyományos telefonrendszerről felsorolt téves felfogások és velük szemben a valós tények ismeretében, a területi fejlesztés céljait mint az alábbi két tényező közti egyensúlyt fogalmazhatjuk meg:

- Az egyik tényező a termelői képesség folyamatos fejlődése, mely az adott térségben erôsen versenyképes gazdasági alapot teremt és tart fenn,

- oly módon, hogy közben csökken a dualizmus ${ }^{40}$ - a nagy és kisebb vállalkozások, a hazai és külföldi tulajdonú beruházások, az újító jellegú és stagnáló vállalkozások, illetve a fejlettebb és kevésbbé fejlett területeken található vállalkozások között.

- A másik tényező az életminőség emelkedése, amely az oktatás, egészségügy és az életkörülmények színvonalának széles körű javulásával jár,

- oly módon, hogy folyamatosan csökken a dualizmus - a digitális szakadék vonatkozásában, a jövedelmek okozta polarizációban és a szocio-kulturális (etnikai, nemi, faji, földrajzi) státus különbségekben,

- s olyan fenntartható formában, amely a terület kulturális identitásának folytonosságát erôsíti.

\section{Következmények}

Ez a célkitüzés természetesen nem egy maximalizálandó matematikai változó, hanem inkább a kivánt elôrrehaladás irányának, minôségének, és mértékének meghatározása. Az elörehaladás egy régió történelmileg kialakult egységének és identitásának keretei között zajlik, amit az emberek értékelnek és magukénak éreznek. Ez az egység és identitás nem zárja ki sokféle feszültségnek a lehetốségét, amelyek esetenként a régión belül komoly belsố ellentétekben is jelentkezhetnek.

Minden pillanatban a terület termelői bázisa és lakóinak életszínvonala verseng a helyi erôforrásokért. Viszont hosszabb távon a fejlesztések kölcsönösen erősítik egy- 
mást. A jobb termelői bázis megteremti az életminőség javításához szükséges eszközöket, és fordítva, a magasabb életminőséggel járó jobb oktatási és egészségügyi színvonal lehetôvé teszi, hogy egy terület magasabb termelékenységet és erôsebb nemzetközi versenyképességet érjen el.

Ezzel szemben, a jelzett dualizmusok megmaradása általában akadályozza a fejlesztést. A termelésben a dualizmusok nemcsak hogy a termelési rendszer hiányosságait jelzik, de az életminőség javulását is visszafogják. És fordítva: az oktatás és az egészségügy színvonalának terén jelentkező dualizmusok nemcsak hiányosságok a régió életminőségében, de a magasabb termelékenység elérését is akadályozzák.

A különböző fajtájú dualizmusok erôsítik egymást, és az összefüggés és összhang alacsony szintjét eredményezik a régió társadalmi szerkezetében. A hiányos integráció megrekeszthet egy-egy területet a fejlettség alacsony szintjén, mert csökkenti a régió képességét saját problémáinak felismerésére és leküzdésére. Mind a termelés, mind az életminőség fejlesztése feltételezi, hogy a régió belső erőforrásai közösen elfogadott irányban, lehetôleg egymással párhuzamosan fejtsék ki hatásaikat. Egység hiányában a belsố erốk közös iránya megbomlik, és összhatásuk csökken vagy megbénul.

Ez arra mutat, hogy a digitális szakadék gyakran egy összetettebb probléma tünete és ezért megoldása nem lehet sikeres, ha csak egy irányból közelítünk felé. (Errôl a késốbbiekben lesz szó bôvebben.)

\section{A TÁRSADALMI KOMMUNIKÁCIÓ IKER-INFRASTRUKTÚRÁJA}

A GEF kommunikációs hálózatoknak elsőrendű fontosságú szerepe lehet a fent említett regionális fejlesztési célok elérésében. Azoknak a területeknek a sikere, amelyek ilyen hálózatok révén kívánnak lépést tartani a globális tudásgazdaság és tudástársadalom beindulásának egyre gyorsuló ütemével, annak a felismerésétől és megfelelő kiaknázásától függ, hogy a társadalmi kommunikáció folyamata két infrastruktúrára támaszkodik. Ezek, bár teljesen különböznek egymástól, mégis szoros kölcsönhatásban múködnek.

- Az egyik egy „kemény” („hard”), Gigabit-sebességű kommunikációs infrastruktúra, amely széleskörű, alacsony költségű hozzáférést biztosít, s hatalmas mennyiségû információ rendkívül gyors áramlását teszi lehetôvé. Ennek az infrastruktúrának ma a GEF a vezető technológiája. A GEF sebességével lehetségessé válik a gyors, közvetlen videókapcsolatok kialakítása, a közvetlenül aktív kapcsolatban álló számítógépek hálózatának megszervezése (GRID), és más, feltörekvố technológiák használata.

- A másik egy „puha” („soft”) társadalmi infrastruktúra, mely a történelem során alakult ki, s kulturálisan beágyazódott, közösség-specifikus hagyományokat, értékeket és kapcsolatokat hordoz. Ez teszi lehetôvé a tanulást, az új tudásanyag kiváló minôségú létrehozását és az újító vállalkozások fejlesztését a helyi termelési lehetôségek javára.

\section{A "kemény" infrastruktúra}

A „kemény”, technikai alapú telekommunikációs infrastruktúra jellemะő tulajdonságai a sávszélesség, az elérhetöség köre, a költség és a nyitott hozzáférés. A gyakorlatban ez felveti ast a kér- 
dést, hogy egy terïlet milyen gyorsan és milyen széles körben tud integrálódni az alacsony költségü, Gigabit-sebességü, végponttól végpontig haladó optikai szálat hasænáló Internet-hálózatok most meginduló forradalmához, melynek Kanada és Svédország az úttörốje. ${ }^{4 l}$ Az Ethernet fejlesztése (vagyis a GEF) a technológia alacsony költségeit még tovább csökkentette.

Jelenleg a telekommunikációs cégek a nagy sebességü optikai sáalat - a korlátozott mértékú tudományos és üzleti alkalmazásoktól eltekintve - föleg távolsági telefon-gerincvonalakhoz, a helyi telefon-vagy kábelTV központok összekötéséhez és korlátozott számban, a kormány vagy nagyvállalatok által bérelt drága és nagysebességü magánvonalakhoz hasะnálják.

A széleskörü és alacsony költségü hozzáférést biztositó Gigabit-sárszélességü telekommunikációs infrastruktúra hatalmas mennyiségü, tárolt információ gyors elérését tesæi lehetövé. Ezen kivül gyors kommunikációt biztosit egyének és csoportok között a régión belül és az egész világon. Ezek nélkülözhetetlenek a versenyképes pozíció megtartásához egy gyorsan terjeszkedó tudásgazdaságban.

A régiókban a GEF telepitésének elórehaladása végül is ast jelenti, hogy aะ optikai szálat a: otthonokba is bevezetik. Ez egy mindenhez vagy majdnem mindenhez alkalmazható hozzáférési rendszert jelent, ami a telefon által nyújtott, hagyományos, személyes hangkommunikáció elórehaladott hasonmása.

Ha a GEF a otthonokba is eljut, ez egyben azt is jelenti, hogy azok - a kisebb vagy közepes méretü cégek, vagy a civil szféra szervezetei - is hozzájuthatnak optikai szálas hálózatokhoz, amelyek eddig nem engedhették meg maguknak a költséges magánvonalakat.

\section{A "puha" infrastruktúra}

A társadalmi kommunikáció második, alapvetôen különbözố, de szorosan kapcsolódó tartóoszlopa a "puha” infrastruktúra. Est a történelem során létrejött társadalmi hagyományok és kapcsolatok minösége képviseli. Jellemsői a konkrét közösségekbe való kulturális beágyazódottság, a lassú változás és az, hogy más közösségekbe nehezen vihetố át. ${ }^{42}$

$A$ „puha” infrastruktúra kritikus szerepet játszik a régió iparszerkezetének élenjátó, legdinamikusabb komponensénél, melyet a magas értéket termelö, specializálódott, világszinten versenyképes iparágak képviselnek. Ezeknek a kiválósága olyan fokú, hogy máshol nem lehet egykönnyen azokkal lépést tartani vagy azokat utánozni.

A „puha” infrastruktúra szerepe kevésbé kritikus a regionális termelés másik két fontos komponensénél:

- Múszaki vagy vegyi alapú iparágaknál, amelyek egy korábbi iparosítási korszak élenjáró technológiáját képviselték, és melyeknek foglalkoztatási igénye az információs technológia nyújtotta észszerűsítések nyomása alatt csökken.

- Szolgáltató-iparágaknál, melyeknek nagy része jellemzően egyre kevesebb nemzetközi értéket termel. ${ }^{43}$

A „puha” infrastruktúra lehetôvé teszi, hogy az olyan magas színvonalú, specializálódott termeléssel foglalkozó területek, mint a Szilikon-völgy vagy Észak-KözépOlaszország a világverseny élvonalában maradjanak.

Ez a két terület teljesen különböző. A Szilikon-völgy egy vezetô, modern technológiát és agresszívan innovatív vállalkozói kultúrát képvisel, míg Észak-KözépOlaszországban inkább a kivételes esztétikai érzék és a vásárlók igényeire való kivételes fogékonyság dominál. Itt a kis- és középvállalkozások virágzanak, amiknek öszszefonódása a családi és közösségi kötelékekből ered. 
A két régióban azonban mégis van valami alapvető közös vonás. Mindkét területre jellemzőek azok a termelővállalatok, amelyek képesek egyedül vagy együttesen részt venni az épp zajló tanulási folyamatokban. Ezen kívül mindkettố kitûnik abban, hogy folyamatosan olyan magas színvonalú, új termékeket és szolgáltatásokat hoz létre, amelyek nemcsak a saját közösségük, de a világpiac sokszerû igényeit is kielégítik. ${ }^{44}$

A történelem során kialakult hagyományokkal és kapcsolati rendszerekkel bíró közösségekre szolgálnak még példaként a párizsi divat- és parfümiparágak vagy a New Yorki pénzügyi szolgáltató iparágak. A hagyományok és kapcsolatok ezen esetekben is magas szintû́ tanulási készséget, kiválóságot és világszintú versenyképességet jelentenek.

\section{A "kemény" és a "puha" infrastruktúra közötti kölcsönhatás}

Ez a két kommunikációs infrastruktúra határoza a meg, hogy a régió mennyire tudja has:nát látni a globális tudásgazdaságnak. Ennek mértéke függ magától a két tényezôtôl, de még inkább a köztük lévố kölcsönhatástól.

A két infrastruktúra közti kölcsönös viszony mindkettőjüket erősíti. A GEF telepítése ösztönzôleg hat a közegészségügy és az oktatás fejlesztésére csakúgy, mint a terület termelési szerkezetére, ami a bevételek növekedésén mérhetố le. Mindezek segítik a „puha” infrastruktúra korszerúsítését. És ez fordítva is múködik: a „puha” infrastruktúra fejlesztése lehetôvé teszi kifinomultabb technológiájú termelési rendszerek és felszerelések használatát, valamint erôs gazdasági, társadalmi és politikai igényt támaszt a már meglévő telekommunikációs hálózatok radikális minőségi feljavítására és gyors kiterjesztésére is.

Ezen felül a két infrastruktúra közti kölcsönhatás, ami az Internet technikai lehetőségeit kihasználó emberi tanulásban és találékonyságban jelentkezik, egy újfajta „innovációs közterületet” hoz létre. Ennek az innovációs közterületnek ${ }^{45}$ nyílt múködése alapvetố fontosságú ahhoz, hogy egy régió magas színvonalú, specializált termeléssel fenntartsa, vagy javítsa helyzetét a globális versenyen alapuló tudásgazdaságban. Egy ilyen jellegú gazdaságban a magas értéket képviselő termelés a megszerzett és beépített új tudásból születik.

Ennél is fontosabb, hogy egy tudásgazdaságban csak a tudás tudja felhasænálni a tudást, vagyis egy ilyen gazdaság logikája megkívánja, hogy az emberek ismeretekben minél gazdagabbá váljanak - beleértve a gyakorlati hozzáértést tudás alapú eszközök használatához is - azért, hogy a már meglevố tudás birtokában képesek legyenek az újonnan kovácsolt tudást befogadni. Ez fordítva is igaz: csak kiterjedt „tudásfogyasztás” teremtheti meg az alapjait annak a társadalmi termelésnek, alkotásnak, amely új, élenjáró tudást hoz létre, és amely a tudásalapú termékekben valósul meg. ${ }^{46}$ Ennek a tudáslétrehozó körforgásnak a folyamatos múködése az innovációs közterülettől függ, amely mind az elméleti, mind a gyakorlati tudás közös fejlődését szolgálja: A fejlesztés szabadságának elfojtása megsemmisíti ezt az önerôsítő kört és tönkreteszi a regionális fejlődést. Ezért olyan veszélyes az, hogy sok régióban a kormányzati szabályozás szervei kiszolgálják a beágyazott telefon- és kábeltársaságok jelenlegi duopóliumának érdekeit, hiszen ez visszaszorítja a GEF telepítésalapú versenykihívását.

A GEF-hálózatok teljesen új lehetôségeket biztosítanak az innovációs közterület működtetéséhez: széles körben elérhetővé és a gyakorlatban használhatóvá teszik 
azt a gyors adatátvitelt, amely támogatja az újításokat a tudományos, az üzleti és a társadalmi élet minden területén, beleértve a telekommunikációs infrastruktúrát is.

Végül az innovációs közterület széleskörû elérhetôsége és kielégítô múködése többet jelent azoknál a versenyképességet növelő előnyöknél, amelyekben a terület közvetlen módon részesül. A mai világban az ilyen múködés alapvető feltételévé válik a nyílt társadalom fenntartásának - ami talán egy régió életminőségének legfontosabb kulturális meghatározója - és ugyanakkor mind a termelékenységre, mind a versenyképességre hosszútávú, kedvezô hatást gyakorol.

\section{A GEF REGIONÁLIS ELŐNYEI}

Ez a fejezet azokat az elönyöket vizsgálja, amelyek egy régión belül a felhasználó egységek javára válnak a GEF sikeres, olcsó és széleskörü telepitése révén - oly módon szervezve, hogy az optikai vonalak csatornái a civil szféra szervezeteinek vagy a közösségeknek a tulajdonában legyenek, hogy maguk az optikai vonalak az elosztó pontokig a végsó felhasználók tulajdonát képezzék, és hogy ezek az optikai vonalak minden tartalomszolgáltató számára sæabad piaci verseny alapján hoz:áférhetök legyenek. (Errôll a telepitési modellröl a késöbbiekben lesz s*ó.) A fejtegetés feltételezi, hogy a régió „puha” infrastruktúrája eléggé fejlett47 ahhoz, hogy lehetốvé tegye az új GEFhálózatoknak folyamatosan javuló hatékonysággal való használatát.

A gigabites sebességü, optikai vonalas Internet-hálósatok felhasænálóinak elönyei vagy az eddig is lehetséges múködések gyorsabb, olcsóbb és hatékonyabb megvalósításából erednek, vagy aะ optikai vonalak has:nálatával a ma még teljesen elérhetetlen új sæolgáltatások és lehetöségek alakjában jelennek meg.

\section{Háztartások és közepes vagy kisvállalatok}

- Hang-, videó- és adatforgalom áttevődése az Internetre. A háztartások és kisebb vállalkozások a GEF telepítésének terjedésével fokozatosan nagymértékủ költségcsökkentést könyvelhetnek el a telefon, kábel és Internet integrálásával, amely a közvetlen összekötést nyújtó, a felhasználó birtokában lévô egyetlen optikai vonalon fut, és amelyhez egy szimpla, olcsó felhasználói program ad hozzáférést. Jelenleg ezeket a szolgáltatásokat külön számlázzák a telekommunikációs cégek, a kábeltársaságok és az Internet-szolgáltatók (ISP=Internet service provider), lehetôleg monopol magasságú árakon.

- Az ingyenes hang- (telefon), videó- (telekonferenciák) és számítógépes adatátvitel azonnal lehetôvé válik két partner közt, akik mindketten rendelkeznek a megfelelő számítógépes programokkal és optikai szálon alapuló Internet-kapcsolattal a felhasználók tulajdonában lévő helyi hálózaton. Ez a rendszer gyorsan el fog terjedni, a helyi hálózatok közötti kölcsönös, szokásosan ingyenes információ továbbítás (peering) alapján. A kétirányú, szimmetrikus, nulla határköltséggel futó Internet-hozzáférés gyorsan elérhetôvé válik, ami lehetôvé teszi, hogy a felhasználók saját Internet szolgáltatóikkal (szervereikkel) rendelkezzenek.

- A kábeltévé, melynek csatornáit egy szabad versenyen alapuló környezet- 
ben nem lehet monopol árú kényszercsomagokba csoportosítani, ehelyett egyes tévé vagy moziprogramonként választható extra szolgáltatássá válik.

- A telefonszolgáltatás az optikai helyi hálókkal még össze nem kapcsolt telefonfelhasználók elérésére szükségképp a telekommunikációs cégekkel való megállapodásokon kell, hogy alapuljon.

- Új lehetôségek az otthoni betegellátásban és az ehhez kapcsolódó területeken. A piaci verseny alapján ellátott, alacsony költségú szolgáltatások közé tartozik például az Interneten eszközölt orvosi „házi látogatás”, az operáción átesett és járóbetegek folyamatos otthoni méréses megfigyelése, vagy az idősek folyamatos táv-ellenôrzése otthonukban, esetleges balesetek és egyéb krízisek kezelésének szempontjából. ${ }^{49}$

- Új szabadidős sæolgáltatások. Internetes újságok előfizetése, interaktív játékok, vagy sokféle, az otthontól távol esố eseményeken vagy rendezvényeken való interaktív részvétel.

- Nagy adatigényü internetes kereskedelmi lehetőségek kisvállalkozások számára. Például: telekonferenciák, ingatlanok távolból történô interaktív bemutatása és bejárása, vagy áruk távolból történô „kézbentartása” és háromdimenziós interaktív forgatásának lehetősége az érdekelt vevők részére.

\section{Iskolakörzetek}

- Az iskolák számára mind oktatási, mind költségkímélési szempontból annyira elónyös a GEF, hogy eæek sæinte mindig kritikus sæerepet játsæanak a GEF telepitésének első sæakasæában mind a városi, mind a vidéki területeken.

- Az iskolák szemszögébốl a legfóbb költségcsökkentések abból adódnak, hogy az Internet szolgáltató egységek (szerverek) koncentráltabbak, jobbak, kevesebb és ilyen egységre és kevesebb Microsoft-licencre van szükség, a hálózat gráfja egyszerûsödik és az üzemeltetố személyzet is központosítottabb lesz.

- Jelentős megtakarítás érhetô el az iskolakörzetek telefonköltségeiben is, mert az iskolákon belüli vagy iskolák közti hívások nulla határköltséggel folynak. $\mathrm{Ha}$ több iskolakörzet van összekötve, akkor a kiadásaikat csökkenti, hogy az egyes körzetek közti nagysebességű vonalak bérleti költsége is megszűnik. Mindezek a költség megtakarítások eléggé nagyméretűek ahhoz, hogy az iskolák tulajdonában lévố GEF hálózat telepítésének finanszírozását néhány éven belül letörlesszék ${ }^{50}$

- Mivel a GEF lehetôvé teszi a telekonferenciák mindennapos használatát zérus határköltséggel, lehetőség nyílik a távoktatásra is. Ez azt jelenti, hogy az élenjáró iskolák kiváló tanerői a kevésbé jó helyzetben lévő vagy esetleg a körzeten kívül lévő iskolák számára is elérhetôvé válnak. Mindez gazdagítja a tananyagot és növeli az egyes iskolák tanítási hatékonyságát.

- A rutinszerú telekonferenciák tartalmasabbá teszik a tanári megbeszéléseket, lehetőséget biztosítanak a szülőkkel történő intenzív interakcióra és segítik a tanulók tanácsolási személyzetének hatékony felhasználását.

- Nem várt eredményt hozott, amikor minden tanár asztalára telefon került, az egymással összekötött iskolakörzeteken belüli ingyenes hívásokra. Az össze- 
köttetés lehetővé tette a tanárok közti intenzív tapasztalatcserét és ez a tanítás minôségének jelentôs javulását hozta magával.

\section{Kórházak és egészségügyi központok}

- A kórházak, közülük is főleg a kisebbek és a távolabb fekvők, többféleképpen részesülnek a GEF használatából származó előnyökból:

- Közvetlen kapcsolattartás otthonukban lévố betegekkel, telekonferenciás tanácsolás, operáción átesett betegek és járóbetegek folyamatos méréses megfigyelése.

- Videókonferenciás távkonzultáció specialistákkal.

- Telegyógyászat: kórházi betegeken végzett beavatkozások vagy mútétek, melyeket egy táv-összekötött specialista eszközöl. Az ilyen táv-operációk lehetôsége, amelyet a közelmúltban sikeresen mutattak be ${ }^{51}$ igen nagy közegészségügyi előnyökkel jár, fő́ként elszigetelt területeken élő paciensek számára.

\section{Városok, megyék és tartományok vagy államok}

- Azoknak a városoknak, megyéknek és tartományoknak vagy államoknak, amelyek új üzleti egységeket vagy iparágakat kivánnak területükre vonzani, érdemes befektetni a GEF telepitésébe. Ez sokkal ésszerübb kiadást jelent, mintha ugyanezt az összeget adókedvezményekre vagy egyes vállalatok szubvencióira adnák ki.

- A GEF telepítés további előnyei:

- Jelentôs költségvetési telefonköltség-megtakarítás és egyéb hatékonyságnövelés érhető el azáltal, hogy a kormányzat összeköti az egyetemeket, iskolákat, kórházakat, könyvtárakat, és közhivatalokat egy köztulajdonban lévô GEF hálózattal, mely ugyancsak köztulajdonban lévő csatornákban fut.

- Magánintézmények és szolgáltatók is részt vehetnek a hálózat kiépítésében, társtulajdonosi (kondomínium) alapon úgy, hogy ôk birtokolják és üzemeltetik saját optikai szálaikat a köztulajdonú csatornarendszerben. A társtulajdonosoknak, akár közületek, akár magánszervezetek, egyaránt előnyös a csatornák amortizációs és karbantartási költségeinek megosztása.

- A GEF hálózat telepítése komoly előnyöket hoz a magánvállalatoknak, amelyek csekély költséggel hozzákapcsolódhatnak a hálózathoz, s ezáltal növelhetik versenyképességüket. Amellett a GEF által létrehozott közegészségügyi és közoktatási fejlesztések az üzleti termelékenységet is fokozzák.

- A városi, megyei, tartományi vagy állami hálózat még értékesebbé válik a felhasználók számára, ha egyrészt kölcsönös hozzáférési alapon kapcsolódik a nemzeti gerinchálózathoz, és másrészt ha megfelelốen elhelyezett üvegszál elosztó pontokkal van tervezve és telepítve, hogy azokhoz aztán az otthonokat és a kis és középvállalkozásokat elérô helyi hálózatok kapcsolódhassanak. ${ }^{52}$ 


\section{A nemzeti szint}

Nemzeti szinten a GEF telepítése alapvetố fontosságú az ország globális versenypozíciójának fenntartása és fokozása, valamint az állampolgárok életminőségnek javítása érdekében.

- A GEF telepítése nagymértékben növeli a vezetô egyetemi- és magán-kutatóintézetek tudományos és technikai teljesítményét. Például a „rácsos számítástechnika” (,grid computing”: számítógépek olyan összekapcsolása, melyben lehetốvé válik a terhelés megosztása, s az, hogy egyetlen, fokozott teljesítményú entitásként kezelhetôvé váljanak - a szerk.) a közelmúltban vált a gyógyszerészeti kutatások fontos eszközévé, melynek segítségével a fehérjék hajtogatásos szerkezeteit (protein folding) és az egyéb, rafináltan összetett biológiai jelenségeket tudják vizsgálni. ${ }^{53}$

- A GEF telepítése lehetővé teszi a kormányzat hatékonyságának növelését minden szinten. Helyi szinten lehetségessé válik a közoktatás és a közegészségügy hatáskörének és minőségének javítása. Interaktív portálok segítségével az emberek elektronikusan intézhetik ügyeiket a kormányzati irodákkal („e-kormányzat”), ami nagy idômegtakarítással jár.

- A GEF telepítésének talán legfontosabb, az egész társadalmat érintố haszna az Internet óriási mértékben megnövekvő sebessége és teljesítőképessége. Ez nyílt, korlát- és szabályozás-mentes hozzáférést biztosít bármilyen információ és kapcsolat számára, amely a nyilvánosság szférájába esik, ugyanakkor a tulajdonjogú információ szféráján belül erősen serkenti a feltalálói és vállalkozói tevékenységet.

\section{A KEMÉNY INFRASTRUKTÚRA ÁTÁLLÁSI KÉRDÉSEI}

\section{A jelen helyzet összegzése}

Ma már létezik egy jól megalapozott új technológia arra, hogy a gigabites sebességű Internet nemcsak a nagyobb intézményekbe vagy vállalatokba, de szerény költséggel az otthonokba és kisvállalkozásokba is eljusson. Így adva van annak a lehetôsége, hogy a villámgyors Internet-hozzáférés olyan elterjedtté váljék, mint most a telefon használata.

Ennek ellenére ma az a helyzet a legtöbb régióban, még a fejlettebbekben is, hogy az optikai üvegszál alapú telekommunikációs forradalom még nem érte el a lehetséges felhasználók nagy többségét. Ezek még mindig a telekommunikációs- és kábeltársaságokra vannak utalva, amelyek a hagyományos szolgáltatásaikon kívül, Kilobit-sávszélességú, vagy alig Megabit-sávszélességú szolgáltatásokat nyújtanak, amely a GEF-en alapuló optikai szélessávú hálózatoknál sokkalta lassabb múködési sebességet jelentenek.

Jelenleg a telefon- és kábelrendszerek a nagytávolságú információ átvitelt gigabites sebességú optikai szálakkal valósítják meg kapcsoló központjaik között, amelyek az előfizetôk közelében helyezkednek el. A helyi hozzáférés - az előfizetőig eljutó „első és utolsó kilométer" - mégis rézvezetéken vagy koaxális kábelen történik, ami még a 
legjobb esetben is (tehát DSL vagy kábelmodem esetén) nagyságrendekkel csökkenti a végponttól végpontig terjedô átvitel sávszélességét. Az a Gigabit-sebességú optikai hálózat telepítés, amelynek célja az információ helyi átvitele a végső felhasználóhoz az elsố vagy utolsó kilométereken át, s ami Internet Protokollt használ Ethernet technológiával, mintegy nyolc-tízszer olcsóbb, mint a hagyományos telefontechnológiák, amelyek hangátvitelre tervezett drága kapcsolóberendezéseket használnak. A GEF előnyei a kábellel szemben is hasonló nagyságrendűek.

Nem kétséges, hogy eltúlzott az a közkeletú benyomás, amely szerint a beágyazott telefon- és kábeltársaságoknak szinte korlátlan ellenálló képességük van az optikai szélessávú hálózatok és főleg a GEF terjedésével szemben. Mégis ma az a helyzet, hogy a legtöbb felhasználót gúzsba kötik ezeknek a társaságoknak az egyéni érdekeltségei és az elavult szabályzó rendszerek, amelyek épp ezeket az érdekeket támogatják.

\section{A legjobb hálózat}

\section{$A$ legegyszerübb a legjobb}

A hírközlés mai helyzetében aæt látjuk, hogy a legegyszerübb optikai hálózatok a legjobbak a területi fejlödés elösegitését tekintve. Ezek a hálózatok minden szürés nélkül teljesen nyitottak arra, hogy mindenfajta információt egyenlö feltételekkel közvetítsenek. Nem tesænek semmi mást, csak a: információ bitjeit szállítják Gigabit / másodperc sebességgel, az optikai Internet Protokollt (TCP/IP) használva vagy közvetlenül, vagy Etherneten.

A legjobb hálózatok a közösségi használat szempontjából tehát akkor a legjobbak, ha nincsenek intelligens hálózatoknak tervezve, vagyis ha nem optimalizálták őket olyan speciális célokra, mint hang-, zene-, TV-, adatátvitel, pénzügyi átutalások, biztonsági-, számlázási vagy tartalomellenőrzés. Amikor ilyenfajta speciális hálózati képességek vannak jelen, általában az eladási bevételeket erôsítô (marketing) eszközökként múködnek. Ezeket a hálózati felszerelések tulajdonosai alkalmazzák egyrészt arra, hogy drága kintlevôséget hozzanak létre a magas szabályozási árak megalapozására, és másrészt, hogy közvetlen ellenôrzést gyakoroljanak a hozzáférés és a tartalom felett, versenyelőnyük előmozdítására.

A telefonrendszer olyan intelligens hálózat, amelyet alacsony sebességű hangtovábbításra optimalizáltak. Egy egészen különálló fizikai hálózattal tervezték meg, amely párhuzamosan futva megkettôzi az átvivố hálózatot, hogy olyan visszajelzéseket küldjön oda és vissza, amelyek múködésbe hozzák a kapcsolókat. Ezek ellenőrzik az átvivő hálózatot és egy megszakítás nélküli elérési utat hoznak létre a hívás kiindulópontja és a célállomás között, a hívás egész ideje alatt.

Ezzel szemben az egyetlen visszajelzés a TCP/IP Protokoll alatt múködő legjobb hálózatoknál abból ered, amikor a külön-külön hálózati utakon csomagonként továbbított bit-lánc egy-egy számozott csomagja (packet) nem ér célba és onnan vissza kell jelezni, hogy küldjék ismét. ${ }^{54} \mathrm{Az}$ alacsony sebességú Interneten keresztüli távgépelő (teletype) és távbeszélő alkalmazásokban (mint az ICQ55), amiket helyi nemoptikai vonalak közvetítenek, megfigyelhetôek alkalmankénti akadozások a gépelt szöveg vagy a hang átküldésében, amiket a csomagok elvesztése és újraküldése okoz. Ezek a fennakadások nem okoznak különösebb problémát a továbbított szöveg folyamatos olvasásában, viszont a hangtovábbítás esetében a minőség emiatt olykor elég 
gyenge. De a Gigabit / másodperces sebesség mellett az akadozások észrevehetetlenné válnak - és ez a hagyományos telefonhálózat telepítési költségének csak az egytizedébe kerül.

A felhasználók által igényelt különleges, prémium kategóriájú speciális tulajdonságok és alkalmazások könnyen megvalósithatók a legjobb hálózat perifériáján, vagyis az optikai szál végén bizonyos weboldalakhoz való hozzáféréssel, míg a hálózat radikálisan egyszerü információ továbbitó funkciói váltosatlanok maradnak.

Például, a hálózati biztonság elérhetó az egyszerü hálózaton az átvitt információ értelmezésének (code) titkositásával, bö tartalék kapacitással, ami más szempontból is fontos, és a hálózati betyárok (hacker) információs árhullámainak (spam) kiszürésével, amik esetleg rosszindulatúan túl akarnának terhelni egy-egy weboldalt. Most már sokan látják, hogy ez elérhetô, méghozzá sokkal nagyobb biztonsággal, mint amit a régi módszer - a nyílt hozzáférésû Internettôl teljesen elzárt magánhálózatok létrehozása - kínált. Kiderült, hogy szinte lehetetlen ilyesfajta teljes elzártságot garantálni és egyetlen álcázott közös hozzáférési pont romba dönti az egész magánhálózat teljes biztonságát.

A legjobb hálózat legfőbb erôssége az az általános jelleg, ami többfajta használatot tesz egyszerre lehetôvé, és ezzel együtt az újításra való nyitottság. Az utóbbinak lényege az alkalmazkodás képessége olyan egészen újszerú felhasználási módokhoz, amelyeket lehetetlen előre látni. Egy ma intelligensen optimalizált hálózati képesség a fejlődés szúk keresztmetszetét jelentheti a jövốben, míg az egyszerúség a jövớben is helytálló lesz.

\section{Finanszírozási kérdések}

\section{A legjobb hálózat pénzügyi paradoxonja}

A legjobb hálózatok egy paradoxonnal járnak. Épp azok a tulajdonságaik, amelyek a felhasználók és a területi fejlődés érdekeinek a szemszögéből a legjobbak, azok teszik ezeket a hálózatokat legrosszabbá arra, hogy kedvezố piaci haszonnal múködjenek.

A legjobb hálózat paradoxonja azért jön létre, mert ahogy a hálózat veszít intelligenciájából, az információátvitel határköltsége is úgy csökken, lényegében nullára. Ha erôs a tényleges vagy a lehetséges verseny, akkor a hálózathoz való kapcsolódás szolgáltatása tömegáru (commodity) jellegú lesz, amelynek piaci ára az átvitt információ mennyiségétől függetlenül legfeljebb arra a nem túl vonzó „normális” nyereségértékre esik vissza, amit a gazdaságelmélet az effajta, szabad versenyen alapuló szolgáltatások beruházásainak bôvítésére indokoltnak számít.

Ez a következmény csak monopolizációval és mesterséges hiány elóidézésével kerülhető el. És még így is nehéz egy legjobb, azaz egyszerủ hálózat monopolisztikus kihasználását politikai segítség nélkül fenntartani, mivel:

- A piacra lépés költsége alacsony, például, egy párhuzamosan megkettőzött telefonhálózat felállításához képest.

- A telepítés szempontjából legvonzóbb területeken, az USA és Európa nagy népsûrûségú nagyvárosaiban egy többé-kevésbé nyílt piac kettő, néhány helyen esetleg három versenytársat is elbír, így nehéz fenntartani a vonzó monopolisztikus ár- és nyereségszintet. 
Még azok a piacok is, amelyek egynél több kereskedelmi szolgáltatót nem tudnak eltartani, ki vannak téve - hacsak nem esnek politikai védelem alá - a felhasználó közvagy társtulajdonosok lehetséges megjelenésének, akik alacsonyabb költségekkel osztják meg hálózataikat és azoknak csatornáit (lásd késóbb). Így a magában álló kereskedelmi szolgáltató ármeghatározó hatalma folyamatos nyomás alatt lesz. Ezen felül, az alacsony népsűrúségú területek amúgy is képtelenek lesznek kereskedelmi szolgáltatókat odavonzani és megtartani köz- vagy kereszttámogatás nélkül.

A beágyazott telefon- és kábeltársaságok ezzel mind tisztában vannak, ezért nem is ruháznak be a legjobb hálózatokba, amelyek az elsôtôl az utolsó kilométerig terjednek, egészen a végfelhasználókig. Épp ellenkezôleg, ezek a vezetố szolgáltatók megragadják az összes lehetséges szabályozási- és politikai eszközt arra, hogy akadályozzák azokat, akik megpróbálnának befektetni ezekbe a hálózatokba.

Ugyanezen oknál fogva a tôkepiacok nem támogatják azoknak a lehetséges versenytársaknak a megjelenését, akik hajlanának arra, hogy az új optikai technológiát alkalmazzák a beágyazott telefon- és kábeltársaságok ellenében. ${ }^{57}$

\section{A pénzügyileg vonzó hálózat közérdeki paradoxonja}

A pénzügyileg kedvezó háló:atok egy ellentétes paradoxont idésnek elō. A paradoxon lényege aะ, hogy azok a tulajdonságok, amelyek a jövedelmező hálózatokat vonzóvá teszik a pénzügyi piac számára, egyben lefokozzák azoknak értékét a közösség elönyeinek szemszögéböl és így veszélyestetik a területi fejlödést.

Hogy lássuk és összevessük a különbözô versenylehetôségeket, érdemes ezeket egy táblázatban összegezni, ahol a rendezési szempontokat a hálózati vonalak telepítésének tulajdonformái, az átvitt tartalom forgalmazása (marketing), vagy ezeknek együttese jelentik.

- A hálózati vonaltelepítés alapú verseny (facilities based competition) esete olyan tulajdonosok között, akik nem visznek piacra semmilyen tartalomszolgáltatást, már a „Legjobb hálózat paradoxonja” fejezetben került megvitatásra (1.1 rubrika).

- Olyan versenytársak, akik a nyílt Interneten speciális tartalmakat (beleértve alkalmazásokat vagy szolgáltatásokat) forgalmaznak, de maguk nem rendelkeznek hálózati vonaltelepítésekkel és nem is társulnak ilyen vonalak tulajdonosaival, ezáltal egyenlő piaci versenyfeltételek közt szembesülnek; épp ezért csak akkor ígérnek kedvező pénzügyi lehetőségeket, ha kivételesen nagyértékú tartalmakat kínálnak (2.2 rubrika). 


\section{A hálózat tulajdonlási višonyai, a tartalomszolgáltatás} és a verseny csökkentésére alkalmas eszközök

\begin{tabular}{|c|c|c|}
\hline (1) ESZKÖZÖK & (2) TARTALOM & (3) MINDKETTÓ EGYÜTT \\
\hline $\begin{array}{l}\text { Verseny az eszközök } \\
\text { között, amelyek nem } \\
\text { forgalmaznak tartal- } \\
\text { mat; a piac vagy tá- } \\
\text { mogat egy vagy né- } \\
\text { hány szolgáltatót, } \\
\text { vagy senkit sem. } \\
\text { A tartalom nyílt to- } \\
\text { vábbítása. }\end{array}$ & Ugyanaz, mint a $(2,1)$ & Ugyanaz, mint a $(3,1)$ \\
\hline $\begin{array}{l}\text { Nincs verseny a szol- } \\
\text { gáltatók között, akik } \\
\text { két, különbözô pia- } \\
\text { con vannak. }\end{array}$ & $\begin{array}{l}\text { Nyílt verseny az Interneten keresztül a tarta- } \\
\text { lomszolgáltatók között, akiknek célja, hogy ér- } \\
\text { tékeket szerezzenek ajánlataik megkülönbözte- } \\
\text { tésével. }\end{array}$ & Ugyanaz, mint a $(2,3)$ \\
\hline $\begin{array}{l}\text { Verseny az eszközök } \\
\text { ellen, amik nem szol- } \\
\text { gáltatnak tartalmat; } \\
\text { az átvitel tartalma fe- } \\
\text { letti ellenőrzés el- } \\
\text { vesztését eredmé- } \\
\text { nyezi; az eszközök } \\
\text { közti versengéshez } \\
\text { vezet, mint az }(1,1)\end{array}$ & $\begin{array}{l}\text { Ha vannak olyan eszközök, amelyek nem szol- } \\
\text { gáltatnak tartalmat, akkor az átvitel tartalma } \\
\text { feletti ellenôrzés nem tartható fenn. } \\
\text { Máskülönben, a szabályozástól függốen: } \\
\text { - kirekesztik az összes vagy néhány versenyösz- } \\
\text { szetevốt } \\
\text { - a saját tartalmat részesítik elốnyben a } \\
\text { - hálózati központba épített intelligen- } \\
\text { cia } \\
\text { - privilegizált hálózati hozzáférési pon- } \\
\text { tok } \\
\text { - a saját csomagoknak nyújtott elsôbbség } \\
\text { - az idegen tartalmat érintố szoftver-aka- } \\
\text { dályok által }\end{array}$ & $\begin{array}{l}\text { Ha vannak olyan eszközök, amelyek } \\
\text { nem szolgáltatnak tartalmat, akkor az } \\
\text { átvitel tartalma feletti ellenôrzés nem } \\
\text { tartható fenn. } \\
\text { Máskülönben, a szabályozástól függöen: } \\
\text { - különbözô piacokra történô, tartalom } \\
\text { általi elkülönülés, pl. telefon és kábel; } \\
\text { vagy } \\
\text { - a tartalom részleges konvergenciája és } \\
\text { verseny, mint a }(2,2) \text { esetében, pl. } \\
\text { DSL és szélessávú hálózati kábel } \\
\text { vagy } \\
\text { - tartalom teljes konvergenciája, ami az } \\
(1,1) \text {-hez vezet }\end{array}$ \\
\hline
\end{tabular}

A hálózati vonaltelepítések beágyazott tulajdonosai, akik tartalomszolgáltatók is, nincsenek védve olyan versenytársak ellen, akik vonaltulajdonosok, de nem szolgáltatnak tartalmat. Az utóbbi versenytársak lehetővé teszik, hogy mások a beágyazott piacvezetốknél sokkal versenyképesebb feltételekkel szolgáltassanak tartalmakat pl. kábeltévé szolgáltatásokat vagy internetes hangtovábbítást. Ez az árakra gyakorolt nyomáshoz és a nyereség csökkenéséhez vezet (3.1 rubrika).

- A (3.2) és a (3.3) rubrika egy fontos hasonlóságra mutat rá. A (3.2) rubrika az olyan vonaltelepítés-tulajdonosok releváns lehetôségeit jelzi, akik tartalmakat is szolgáltatnak, szemben azokkal, akik vonaltulajdon nélkül szolgáltatnak tartalmat. A (3.3) rubrika két olyan, egymással versengố vonaltelepítés-tulajdonos felet mutat, akik tartalmakat is kínálnak. Mindkét esetben a beágyazott vonaltelepítés-tulajdonos tartalomszolgáltatók mozgástere elsősorban és főként attól függ, hogy vetélkednek-e a piacon olyanfajta erôs versenytársak, akik vonaltelepítésekkel bírnak ugyan, de tartalmakat nem kínálnak. Ha létezik ilyen versengés, akkor az folyamatos nyomást gyakorol a tartalomszolgáltatási árakra. Ha viszont az ilyen verseny korlátozott, akkor fontos védekező stratégiák válnak lehetségessé. 
Annak érdekében, hogy a vonalak felhasználói elégséges piaci szúkösséggel álljanak szemben egy elfogadható haszonszint biztosítására, a vonalak terén közel teljes monopol helyzetet (vagy egy szabályozott monopóliumot) kell egyesíteni a tartalomszolgáltatással. Ezen felül az is lényeges, hogy a hálózatüzemeltetési módszereket úgy kell beállítani, hogy a „legjobb” hálózat két alapvető tulajdonsága közül legalább egy, de inkább kettô módosuljon:

- a hálózat alapjaiba be kell építeni egy megfelelő intelligenciát, amely előnyben részesíti a cég saját tartalmi ajánlatait; vagy

- le kell szúkíteni a cég hálózatának nyitottságát, hogy már ne mindenfajta információt továbbítson egyenlő feltételek mellet.

A fenti stratégiák képezik a pénzügyileg kedvezô hálózat közérdeki paradoxonának lényegét. Ezek a stratégiák alapvető fontosságúak ahhoz, hogy az elsô és utolsó kilométert fedô optikai vonalak telepítésébe befektetett tôke kedvezố hasznot térítsen meg. Ugyanakkor ezek azok a stratégiák is, amik lerontják a „legjobb” hálózat értékét, megemelik az árakat és megnyesik az optikai hálózat telepítéséból származó, a közösség számára fontos elônyöket.

Még kritikusabban, ezek azok a bizonyos stratégiák, amelyekkel szemben Lessig $^{58}$ óv, amikor a társadalmi „innovációs közterület” bekerítésérôl beszél, mert a nyitott innovációs közterület a mai globalizálódó tudásgazdaságban a regionális és nemzeti versenyképesség fenntartásának és fejlesztésének alappillére.

A követkertetés tehát a:, hogy a területi és a nem:eti fejlödés megkivánja a: olyan GEF telepitési stratégiákat, amelyek tü:falat épitenek a fejlett optikai hálózati infrastruktúra tulajdona, és a hálózatokon átvitt tartalmi szolgáltatások vállalatainak tulajdona között.

\section{Felhasználók tulajdonában lévő hálózatok}

Az előbb tárgyalt két paradoxon rámutat arra, hogy a „legjobb” hálózat nem érdekli a pénzügyi piacokat, és viszont, a pénzügyi piacoknak kedvező hálózatok hátrányosak a közérdekre, a regionális és nemzeti fejlődésre.

Ennek ellenére, a legjobb hálózat finanszírozása viszonylag könnyü, ha a hálózat közvetlen tulajdonjogát (vagy ennek közeli megfelelöjét, a hosszútávú és megújitható korlátlan jogot a használatra (indefeasible right of use - IRU) a hálózat végfelhasználói gyakorolják.

Ez az állítás ugyanazon okok miatt igaz, amelyek megakadályozzák, hogy egy ilyen hálózat a kereskedelmi vállalkozásoknak megfelelố haszonnal múködhessen. Ezek az okok épp azok, amelyek a hálózathoz való kapcsolódás szolgáltatását egy közönséges piaci verseny alapján felkínált árucikké teszik - a hálózat egyszerúsége, általánossága és nyíltsága. Ezek miatt a tulajdonságok miatt a hálózatot jól ismert, könnyen elérhetô és olcsó, készen kapható (a polcról levehetô) technológiákkal meg lehet valósítani.

További pénzügyi előnyei vannak a végfelhasználói tulajdonnak (vagy IRUalapú jognak):

- Az amortizációs periódusok ilyen alapon lényegesen hosszabbak lehetnek, mint ami kereskedelmi vállalkozások számára elfogadhatató lenne.

- A beruházás költségei gyakran fedezhetők kedvezô kamatozású kölcsönökkel, amelyeknek visszafizetését a végfelhasználók folyamatban lévố bevételei biztosítják. 
- A közösségi létesítmények, a civil szféra vállalkozásai, vagy az otthoni felhasználók sok régióban a jelenlegi törvények szerint olyan adókedvezményeket kaphatnak, amelyek kereskedelmi vállalkozások számára nem elérhetôek. Az Egyesült Államokban például, ha lakóház vásárlásakor az optikai kapcsolat kiépítésének költsége a jelzálogba bele van számítva, akkor ez jelentôs jövedelemadó-kedvezményt jelent, mert a jelzálog levonható az adóalapból.

A felhasználók tulajdonában lévő hálózatoknál a hálózat tulajdonosai természetes módon elkülönülnek a tartalomszolgáltató vállalatoktól, ami hatékonyan garantálja, hogy a GEF telepítése a lehetô legtöbb haszonnal járjon a közösség és a fejlôdés számára.

Továbbá, a felhasználók tulajdonában lévő optikai hálózatok a hírközlési szektor mostani szolgáltatás-alapú üzleti modelljét egy felhasználói tulajdonra épített üzleti modellre állítják át - amely tág teret ad a magánszektor múködésének (ezt később bővebben tárgyaljuk). Az utóbbi modell jellemzi például a gépjármú szektort, mely nagyrészt elad, és csak kisebb részben ad bérbe vagy számláz taxi módjára kilométerenként a végfelhasználóknak.

\section{Az IEEE-USA szélesávú műhely alapvető következtetései ${ }^{59}$}

A legjobb hálózat korábban kifejtett elemzései, paradoxonjai, és a felhasználók tulajdonának elốnyei egybehangzanak az IEEE-USA 2002. június 17-18-án Washingtonban megtartott, szélessávú hálózati telepítések irányelveit vizsgáló múhely jelentésében foglaltakkal:

„Az olyan hálózatoknak mint a GEF, két lényeges jellegzetessége van, melyek alapvető fontosságúak a különbözô telepítési módok kiértékelésében. Az elsô az, hogy a hálózat elkerülhetetlenül hajlamos a természetes monopolhelyzet kialakítására. A második, hogy ha a hálózat teljesen ki van építve, akkor a használat határköltségének nullára kell esnia ahhoz, hogy a hálózat [mint közszolgáltatás] hatékonyan múködjék. Elemzésünkból látszik, hogy ha ki akarjuk használni a GEF hálózatok előnyeit, akkor a két jelenséget egyszerre kell kezelnünk. A hálózati tulajdon ösztönző szerkezetének:

- „Semlegesítenie kell annak a lehetőségét, hogy a hálózaton monopólium alakulhasson ki (ez a lehetôség benne rejlik minden hálózatban)

- „Teret kell adnia a közösségi előnyöknek annak biztosításával, hogy a GEF hálózat használatának határköltsége nullára legyen leszorítva, és a használat ára megközelítse a határköltséget. ${ }^{60}$,

A jelentés a monopólium kialakulásáról a következôket állapítja meg:

„A GEF-nek felhasználónként csak egy csatlakozási vonalra van szüksége; ez a vonal válhat a természetes monopólium alapterévé. Egész egyszerúen: egy második csatlakozási vonal megduplázná a hálóhoz való kapcsolódás költségét. ... A most kialakuló telekommunikációs paradigma megengedi a végfelhasználónak ... legalábbis azt, hogy birtokolja és szabályozza kapcsolatát a hálózattal, ... ily módon kizárván annak a lehetôségét, hogy a csatlakozási vonal egy monopolista kihasználás kulcspontjaként múködjék, ehelyett a lehetséges szolgáltatások ,választási kulcspontjává tévén azt. ${ }^{61}$ 
„Azonban, ha egy helyen meg is szüntetjük a természetes monopólium lehetôségét, attól még előbukkanhat máshol. Megjegyzésre méltó, hogy a felhasználói tulajdon alapú telekommunikáció [egyik megvalósítási módja szerint] a végfelhasználó saját magának építi, s maga birtokolja és használja az infrastruktúrát. Mivel a felhasználó kezében van a befektetés, ezért közvetlenül saját maga kontrollálja és blokkolja a természetes monopóliumot, bárhol bukkanna is fel. [Közösségi vagy társas] tulajdonviszonyok esetén hasonló a helyzet. Az az entitás birtokolja a hálózatot, amelyik használja."

Összetettebb tulajdonviszonyok esetén a jelentés a következóket ajánlja:

„... az ösztönzốknek olyan szerkezete, amely a hálózat egymástól elválasztott, külön tulajdonban lévô részeit jól összefüggő módon foglalja össze, a természetes monopólium lehetőségét ilyen körülmények közt is kizárhatja. [Egy javasolt modell] arra alapul, hogy különböző résztvevők birtokában lévő elemek együttesen alkotják a GEF hálózatot. A résztvevốk: (1) végfelhasználók, (2) tartalmak, alkalmazások, és szolgáltatások felkínálói (CAS: content, application, services), (3) egy semleges csoport ( ... leginkább egy önkormányzat vagy közületi hatóság) [amely birtokolja/szabályozza a hálózat szorgalmi jogait és tartószerkezeteit, pl. a vonalak elhelyezésére szolgáló területeket, csatornákat, oszlopokat, stb.], és (4) egy a GEF múködését egyesítő rendszer integrátor és hálózati intéző.62 Ezek a résztvevők együtt egy összefüggő, egyesített rendszert alkotnak, melyben az összes partnereknek egymást kiegészítő múködési ösztönzói vannak. Közösen egy olyan mechanizmussá állnak össze, amely kizárja a természetes monopólium létrejöttét még az ilyen összetett GEF hálózatok esetén is." ${ }^{33}$

Mivel a fentiek alapján a természetes monopolhelyzet kialakulása kizárt, a második cél jön szóba, nevezetesen annak megvalósítása, hogy a GEF hálózat használatának határköltsége nullára legyen leszorítva. Ez könnyen elérhető azáltal, hogy a hálózat szúk pontjaira bő tartalékkapacitás legyen tervezve és kiépítve. Az IEEE-USA jelentés a következő, a benne rejlô paradoxon révén könnyen megjegyezhetô jelmondatot javasolja: „Csak az elég, ami túl sok.”

Ez valójában azt jelenti, hogy az aktuális forgalom feletti többletkapacitás egyben létfontosságú tartalék sávszélesség, amely biztosítja, hogy a forgalom váltakozása és jövendôbeli növekedése - pl. új végfelhasználók belépésekor a társtulajdonba - ne okozzon forgalmi torlódást s így ne emelje nulla fölé a használat határköltségét. Emellett a többletkapacitás fontos a szolgáltatási minôség és a rendszerbiztonság magas szinten tartásának szempontjából is.

A tartószerkezetek szempontjából (ez a 3-as résztvevővel kapcsolatban kerül megemlítésre) a többletkapacitás fontos biztosítéka a rendszer növekedésének. Meggátolja a tartószerkezetek kapacitásának hiányából eredő megtorpanásokat a hálózat bővítésében, és ezáltal a használat határköltségének nulla fölé emelkedését, például olyankor, amikor a meglévố szereplôk új optikai vonalakat kívánnak adni a hálózathoz, vagy amikor egy új versenytárs jelenik meg a rendszerintegrátorok között. 


\section{KANADA: - EGY PÉLDAMUTATÓ ÁTMENET}

\section{Egy háromszintes hálózat}

Kanada tapasztalatai ${ }^{64}$, mivel ez az ország a világelső a kontinens-méretű és regionális GEF hálózatok kiépítésében, nyújtják a legjobb kiindulási alapot a területi és nemzeti GEF hálózatok telepítéséhez Európában és az Egyesült Államokban is.

Kanadában jelenleg folyamatban van egy optikai üvegszál alapú szélessávú országos stratégia megvalósítása, melynek hálózati koncepciója három különbözô szinten múködő hálózatoknak az összekapcsolásából áll. Az elképzelés attól a Nemzeti Bizottságtól származik, amelyet a probléma tanulmányozására állítottak fel a kilencvenes évek közepén, s háromszintes struktúrájában egy centralizált döntéseket feltételezố szerkezet benyomását keltheti, annál is inkább, mivel a telepítés a legfelső szinten kezdődött. Mindamellett a késôbbiek során a kiépítési folyamat széleskörű magán és közösségi kezdeményezésekre, valamint közületi vagy társtulajdonosi megvalósításokra támaszkodott a középső és a helyi szinten, ezért a struktúra kiépítése ebben az értelemben egy lényegesen decentralizált dinamikát is magában foglal.

A legfelsố szint az országos gerinchálózat, mely összeköti a legnagyobb egyetemeket és kutatóintézeteket. A gerinchálózat a csomópontjaiban kapcsolódási pontokat nyújt a következő szint hálózataihoz. ${ }^{65}$

A középső szintet a tartományi, regionális és városi hálózatok képviselik, az esetek többségében különös tekintettel az iskolákra és a regionális egyetemekre, a társtulajdon formájában történô kiépítés első fázisában. Ezek a társtulajdoni hálózatok úgy vannak megtervezve, hogy a kiépítés további szakaszában könnyen hozzákapcsolódhassanak a könyvtárak, kórházak, helyi kormányzati hivatalok, sốt még a hálózat kiépítésében részt venni kívánó nagyobb üzleti partnerek is, beleértve az Internet és egyéb kommunikációs szolgáltatókat. A középső szint csomópontjaiban üvegszál elosztó pontok helyezkednek el, amelyek úgy vannak megtervezve, hogy a harmadik szint eléréséhez a részt vevố szolgáltatók számára egyenlố versenyfeltételeket biztosítsanak.

A legalsó, helyi szint megteremti a közvetlen optikai kapcsolat lehetőségét a háztartások és a kis és középvállalkozások részére, az úgynevezett elsố kilométerek áthidalásával. Ezt gyakran „házig érő üvegszál” néven említik („fiber to the home”, melynek fogalma a lakásokat, házakat, és a kis és középvállalatokat is fedi). Mindeddig ennek a lehetôségnek a gyakorlati kiaknázása csak néhány helyi projekt formájában indult meg. ${ }^{66}$ A „házig érô" modell problémaköre viszont bizonyos értelemben a középső szintre is kiterjed, különösen a tartó struktúrák alapvető fontosságának felismerésével.

Lehet, hogy a kanadai elképzelés fent említett centralizált vonásai nem vihetók át az Egyesült Allamokba, az Európai Unióba, illetve olyan országokba, amelyek decentralizáltabb módon kívánják kezelni az infrastrukturális átállást. Ilyen esetekben legvalószínúbb, hogy a hálózat kiépítése majd a középsố szinten kezdôdik, és lefelé valamint oldalirányba terjeszkedik, s késốbb a földrajzilag szomszédos, középszintû hálózatok kölcsönösen ingyenes összekapcsolásából (peering) alakul ki az országos gerinchálózat. Ezt valószínúleg fokozatosan meg kell majd erôsíteni távolsági törzsvonalakkal a forgalom növekedésének ütemében, míg a kanadaihoz hasonló gerinchálózat ki nem alakul. 
A kanadai telepítés középső és alsó szintjére visszatérve, az oszlopokra függesztett és földbe beásott múanyag mikró-csatornák (micro-conduits), valamint a vastagabb törzsvonalakat kiszolgáló nagyobb alépítmények egy harmadik tulajdonrészét alkotják a hálózatnak. Ezeknek a tartószerkezeteknek a tulajdonjogát feltétlenül el kell különíteni magának az optikai üvegszálnak a tulajdonjogától, s ugyancsak az optikai vonalon továbbított tartalom tulajdonjogától is. Mindezen jogoknak alapos figyelmet kell szentelni a GEF hálózat telepítése során. ${ }^{67}$

\section{Egy újonan felmerülő lehetőség}

Ez a lehetôség az elốbbi három tulajdonjognak a legalsó szinten való elkülönítésére szolgál, amely ösztönzi a legjobb hálózat kialakítását az „első kilométerek” áthidalásával. Elemei a következók:

Mikro-csatornák. Mưanyag csatornák az optikai vonalaknak civil szféra vagy köztulajdon alapú telepítésére. Ezeknek a csatornáknak az optikai elosztóponttól kezdve, kivétel nélkül a helyi projekt területén fekvố minden egyes végfelhasználó pont (lakás, ház, közép és kisvállalat) közvetlen közelében el kell elhaladniuk. Ez akkor valósítható meg gazdaságosan, ha a környéken az összes végfelhasználók megfelelő hányada a projekt kezdetétől fogva hajlandó elkötelezni magát az optikai kapcsolat bekötésére (ismert külvárosi esetekben $30-40 \%$, de ez a helyi sưrúség és egyéb tényezôk függvényében gyökeresen változhat).

Optikai szál behúzása. ${ }^{68}$ Mihelyt a szálcsatornák kiépültek, minden készen áll arra, hogy behúzzák, illetve helyesebben légnyomással „befújják” az optikai szálakat (blown fiber) a már elkötelezett végpontokhoz. Az optikai kapcsolásról szóló megállapodások szerint a háztulajdonosok felelőssége a szál végkiépítése, beleértve a tulajdonos végponti eszközeinek kiválasztását, megvásárlását, az üvegszálhoz való bekötését, valamint az elosztópontnál szükséges optikai szálvégződés kiválasztását és eszközberuházásának fedezését. A később belépő végfelhasználókhoz - a megfelelő csatlakozási költség befizetése után - könnyen befújható az optikai szál a már meglévô szálcsatornába. A szálcsatorna amortizációs és karbantartási költségeinek egy foore jutó része az újabb végfelhasználók belépésével párhuzamosan csökken.

Ott, ahol hiányoznak a megfelelő lehetôségek a szálcsatornák elhelyezésére, az optikai szál telepíthetô oszlopokra, légvezetékként, mint például a Washington államban lévő Grant County-ban. A szálcsatornás megoldás még inkább a tervezőasztalon van, mint a megvalósítás fázisában, és nem olyan olcsó, mint a légvezetékes megoldás. A lényeg mindenesetre a hálózat kiépítése úgy, hogy a tartalékkapacitás ne csak bôséges, de állandóan és olcsón tovább bővíthető legyen, mint azt már említettük.

\section{A TELEKOMMUNIKÁCIÓS- ÉS KÁBELTÁRSASÁGOK JÖVŐJE}

\section{Tárgyalások az átmenetről a telekommunikációs társaságokkal}

A GEF telepítések sikeréhez döntő fontosságú az új GEF technológiai kezdeményezések és a beágyazott telekommunikációs társaságok közötti ambivalens vi- 
szony figyelembe vétele. ${ }^{69} \mathrm{~A}$ GEF telepítésének folyamatában a telekommunikációs társaságokkal való együttmúködés általában véve értékes lehet, ha megoldható. A korábban már telepített, felesleges, tehát sötét optikai szál (dark fiber) megvásárlása jelentősen olcsóbb, mint belefogni egy párhuzamos hálózat kiépítésébe. Amikor pedig sötét szálak hiányában erre mégis sor kerül, a telekommunikációs cégek építési, karbantartási és hálózatmenedzselési tapasztalatai kitûnố partnerré teszik ôket a hálózat létrehozásában.

A kanadai tapasztalatok viszont azt mutatják, hogy amikor a hálózatot kiépítése megkezdődött egy területen, a beágyazott telekommunikációs társaságok folyamatos és határozott ellenállást mutattak a GEF ellen, melynek tere a tisztességes versenytôl az illegalitás határait súroló lépések alkalmazásáig terjedt. ${ }^{70} \mathrm{~A}$ végponttól végpontig terjedő, optikai alapú technológia verhetetlen fölénye a több mint száz éves, rézdrót alapú telefonrendszerrel szemben kétségtelenül egy kitûnố üzleti indok az ilyenfajta ellenkezésre, mindaddig, amíg az fel tudja tartani a GEF terjedését és lehetôvé tudja tenni a meglévô telefonhálózat további kihasználását annak DSL változatával együtt. A telekommunikációs társaságok tudatában vannak annak, hogy Schumpeter kreatív pusztításának kísértete lebeg a szektor felett, amely legjobb esetben is a megszokott üzleti modelljeik újragondolásával és újrarendezésével fenyegeti ôket. Hasonló okokból a kábeltársaságok is mindent elkövetnek, hogy visszafogják a GEF hálózatok telepítését, és ez idő szerint inkább a saját kábelmodemjeik telepítésének sikerében bíznak.

Ennek a beállítottságnak a megváltoztatására nincs remény mindaddig, amíg az elsô GEF telepítések sikere, minősége és költséghatékonysága a beágyazott társaságokat meg nem gyốzi arról, hogy nélkülük is folytatódik a telepítés. Egy jól bevált stratégia ebben a helyzetben abból állt, hogy a munkák kezdetekor a GEF telepítői felajánlották a telekommunikációs társaságnak egy kisebbségi részvétel lehetőségét a telepítésben, és fenntartották az ajánlatot a kezdeti csaták ellenére. Amint a társaság meggyőződött arról, hogy a GEF kiépítése elkerülhetetlen, elfogadta az ajánlatot. ${ }^{11}$

Abban az esetben, ha önkormányzatokkal kell együttmúködni a telefontársaságok ellenállásával szemben, tanácsos elkerülni a közmúvek hivatalait, mert az ottani hivatalnokok fốleg arra fognak törekedni, hogy a meglévố infrastuktúrákra (üvegszálvonalak elhelyezésére szolgáló területek, szálcsatornák, oszlopok, stb.) magas használati díjakat vessenek ki. A polgármesterek viszont természetes szövetségesek, mert könnyen meggyôzhetốk arról, hogy a GEF hálózat segít új vállalkozások megtelepedésében, és ezért mindent elkövetnek, hogy segítsenek. Ugyanekkor nagy figyelmet kell fordítani a nyilvánosságra és a sajtóra azért, mert lényeges szerepet játszanak a telekommunikációs cégek támadásainak kivédésében és a GEF hálózat elônyeinek a közösséggel való megismertetésében.

Az iskolákat, kórházakat, egyetemeket és városi / területi hivatalokat összekötố regionális hálózatok tervezésekor különös figyelmet kell fordítani - részben a telefontársaságokkal való viszony kialakulásának szempontjából, részben öncélként - a következókre:

- az optikai vonalak tartóstruktúrájának többletkapacitására, amelyet úgy kell megtervezni, hogy az a hálózat növekedésével együtt bővüljön, ezáltal megelőzvén egy monopolhelyzet kialakulását;

- a kölcsönös ingyenes információtovábbitás megteremtésére szomszédos közületi vagy területi hálózatokkal, azért, hogy a nulla határköltségú hozzáférés tere 
bővüljön, és hogy a hagyományos telefonrendszerekre való utaltság fokozatosan csökkenjen;

- bốséges elosztópontok bi:tositására a későbbiekben a házig érő optikai hálózat kiépítése számára; és

- Megabit sárszélességü drótnélküli rendszerek átmeneti használatára, hogy a GEF iránti kezdeti lelkesedés ne csökkenjen a kiépítés fázisában, amely akár két évig is elhúzódhat.

A Megabit-sávszélességú drótnélküli kapcsolatok átmeneti használata kombinálható vagy helyettesíthetô a korábban említett múholdas technológiával, amely a várható napi webhasználat zömét lesugározza a felhasználók merevlemezes tárolására. Ez a meglévő alacsony sebességú Interneten csökkenti a torlódás valószínúségét és gyorsítja a felhasználók hozzáférését a tárolt webtartalomhoz. ${ }^{72}$

A kábeltársaságok ambivalens viszonya a GEF kiépítéséhez hasonló a telekommunikációs társaságokéhoz. A kábeltársaságok felett is lebeg a kreatív pusztítás kísértete, s a GEF számára ók is kínálhatnak kedvezô alkalmakat az együttmúködésre. Eladhatnak sötét optikai szálakat, vagy megoszthatják tapasztalataikat a rendszertervezés, karbantartás és menedzselés területén. Mégis szerepük, mind a szembenállás, mind az együttmúködés szempontjából, másodlagos a telekommunikációs társaságokhoz képest.

\section{A telekommunikációs és kábeltársaságok szerepe az átmenetben}

A kanadai tapasztalatok jó irányelveket kínálnak arra, hogy hogyan alkalmas kezelni a telekommunikációs és kábeltársaságokat az optikai szálhálózat telepítése során. ${ }^{73}$ Kanadában ugyan létezik egy nemzeti célkitűzés, hogy a házig érő optikai kapcsolatokat, névlegesen 2005-re, majdnem egyetemesen kiépítsék ${ }^{74}$, mégis az átmenetet fokozatosra tervezték. A felhasználó egységek túlsúlya a társtulajdon alapú kiépítésekben biztosítja az optikai szál tulajdonosai és a tartalomszolgáltatók közti nagymértékű elkülönülést. Ennek ellenére, a múlttal való folytonosság és a telepítés gyorsítása végett, az Internet-szolgáltatók, távközlési cégek és kábeltársaságok részt kaphatnak a középszintû (önkormányzati, regionális és tartományi), társtulajdon alapú optikai hálózat kiépítésében. Ennek során, a szolgáltatóknak a helyi szintủ végfelhasználókhoz való hozzáférését (ami a jövôben majd egyre több házig érô kapcsolatot jelent) a következő sajátosságok kell, hogy jellemezzék:

- Versenysemlegesség, vagyis hogy minden szolgáltató egyenlő hozzáférést kapjon az elosztópontoktól a végfelhasználókig érô optikai szálakhoz;

- Végfelhasználók döntésszabadsága, vagyis hogy tetszés szerint választhassanak a szolgáltatók között, azonnali váltási lehetôséggel;

- Hálózati vonalak és tartalomszolgáltatások tulajdonosainak elkülönítése, vagyis hogy sem a végfelhasználóhoz tartó optikai szál, sem az azt tartalmazó szálcsatorna (melyek kritikus fontosságúak egy lehetséges monopólium megelőzésének szempontjából) ne lehessen olyan cég birtokában, mely bármilyen tartalmakat, alkalmazásokat, vagy szolgáltatásokat kínál fel üzleti alapon. 


\section{A telekommunikációs cégek hirtelen összeomlásának kockázata}

A kemény infrastruktúra átalakitási irányelveinek kidolgozásásakor egyes régiók vagy országok számára, a gyors GEF telepités tervezése és szervezése mellett arra is figyelemmel kell lenni, hogy a regionális fejlödés szempontjából a beágyazott telefontársaságok hirtelen pénะügyi összeomlásának lehetösége egy el nem hanyagolható kockázatot képez, mindaddig amíg a GEF hálózat nagyrésst ki nem épül.

Ezt az összeomlást eredményezheti a telekommunikációs társaságok eltúlzottan magas kötvényadósságainak törlesztési terhe, szemben a prémium-díjas hangforgalmuk fokozatos csökkenésével. Az utóbbi rövid távon a mobiltelefonok, az e-mailek, és a drótnélküli kapcsolatok terjedésének a következménye, hosszú távon pedig várhatóan egyre inkább onnan fog eredni, hogy az integrálódó kép-, hang- és adatforgalom a kiépülố GEF hálózatokra tevődik át. Ha a GEF kiépítése közben ilyen összeomlás fenyeget, akkor kormányzati beavatkozásra lesz szükség, hogy az adott területen a telefonszolgáltatás meg ne szủnjék. A telekommunikációs társaság foglalkoztatásának hirtelen összeomlása szintén rendkívül káros lenne a regionális fejlődésre.

A telekommunikációs társaságok helyzetének hasonlósága az Egyesült Államokban és Európában fontos kérdéseket vet fel azzal kapcsolatban, hogy a regionális fejlesztések szabályozásába a GEF telepítés hogyan illeszkedjék be.

A telekommunikációs társaságok hagyományos információ átvivő szerepét lehetőleg fokozatosan kell helyettesíteni az optikai üvegszálhálózat kiépítésével. Viszont ha a telefontársaságok pénzügyi összeomlásának veszélye fenyegetôvé válik, elôre átgondolt tervek kellenek szükséghelyzet esetére, hogy a régiókat meg lehessen védeni egy kommunikációs katasztrófától. Ezért az optikai hálózat fejlesztésének terveit ki kell egészíteni azokkal az irányelvekkel, amelyek biztosítják a terület telekommunikációs infrastruktúrájának zavartalan müködését.

Ha szükséghelyzet esetére nincsenek elöre megvitatva és kidolgozva az észszerü válaszlépések, akkor igen valószimú, hogy a telekommunikációs cégeknek nyújtott jelentôs, hosszútávú kormányzati támogatás lesz a válasz arra a pánikra, amit egy hirtelen összeomlás okozhat - függetlenül a társaságok magas költségeitól és elavult infrastruktúrájától.

Viszont egy ilyen pánikszerü döntés a kormányzat részéröl rendkivül irracionális módja lenne a regionális fejlesztési alapok használatának. Ezért, ha a telefonforgalom csökkenése túl gyorssá válik, akkor a csödök és elbocsájtások nagyobb kihivást jelenthetnek a regionális fejlödést támogató átállási stratégiáknak, mint a GEF hálózatokra való áttérés felgyorsitása. Egy olyan stratégiának, amely megfelelốn kezelni képes a hirtelen összeomlásokat, két szinten kell kombinálnia a GEF telepitésének hosszútávú érdekeit a szükséghelyzetbeli válaszlépések tervezésével:

Az állami, regionális és helyi kormányzat erőinek fel kell készülniük a: átmeneti pénzügyi segitség nyújtására a meglévó telekommunikációs hálósatok elfogadható müködtetéséhez egyes területeken vagy régiókban mindaddig, amíg a GEF telepitése be nem fejezódik.

Az Egyesült Államok kormányzatának, vagy Európában az Európai Uniónak hatékonyan kell mozgósitania az eröforrásait egy telekommunikációs összeomlás esetére, hogy minden szinten, a szabályozó testületeket is beleértve, támogassa és koordinálja a kormányzati eröfeszitéseket. Ezeknek az eröfeszitéseknek amennyire csak lehet, egy olyan GEF infrastruktúra gyors kiépítésére kell irányulniuk, amely megfelel a korábban meghatározott legjobb hálóaat követelményeinek. 


\section{A hírközlési szektor új üzleti modellje}

A kemény infrastruktúra átállásának irányelvei a következô módon összegezhetôk:

A szélessávú optikai telekommunikációs hálózatoknak (mint a GEFnek) a regionális fejlödés szempontjából legkedvezöbb kiépitése a hírközlési sæektor mostani, sæolgáltatás-alapú üzleti modelljétôl a szektor felhasználói tulajdon-alapú üzleti modellje felé vezet.

Ez tág teret enged a magánszektor múködésének a következô területeken:

- Kiépítés, karbantartás, és az új GEF hálózatok szerződéses felügyelete, amelyben a telefon és kábeltársaságoknak nagy tapasztalatuk van.

- Tartalmak, alkalmazások és egyéb szolgáltatások biztosítása olyan szabad versenykörnyezetben, amelyben a pénzügyi előnyöket az értékes, innovatív kínálatokat felajánló cégek élvezik.

- Olyan kreatív adaptációk, amelyek előre nem látható új szolgáltatásokat és vállalati modelleket képesek létrehozni. Összehasonlításként említésre méltó, hogy az IBM cég, hosszú fennállása során már kétszer is sikeresen átszervezte alapvetố vállalati modelljét. A telekommunikációs ipar kulcsjátékosairól nem kell csak azért lemondani, mert a szektor üzleti modellje nagy átalakulás elôtt áll.

\section{A PUHA INFRASTRUKTÚRA ÁtALAKULÁSÁNAK KÉRDÉSEI}

\section{A teleházak mint az átalakulás eszközei}

A puha infrastruktúra átalakulásával kapcsolatos feladatok kezelésére a teleházak (telecenter, telecottage, technology center) jelentős lehetőséget kínálnak, különösen azokon a területeken, amelyek hátrányban vannak a fejlettebb régiókkal szemben. Ez a fejezet, mint az előzố elemzések, az európai és amerikai kontinens hátrányosabb helyzetben lévő régióira összpontosít, melyek a fejlődés szempontjából az élenjáró régiók és a Harmadik Világ között helyezkednek el.

Az utóbbi években jelentôsen megnövekedett a figyelem a teleházak ${ }^{75}$ múködése során felgyülemlett tapasztalatokra, elsősorban a vidéki elszigeteltség, a digitális szakadék és a szegénység kérdéseivel kapcsolatban. Viszont sok még a kérdés és jelentốsen kevesebb a dokumentált információ arról, hogy a teleházak hogyan hatnak ezekre a problémákra a városokban, különösen a koncentrált nyomor és nélkülözés szomszédságaiban.

Ugyanekkor még kevesen ismerik fel, hogy fejlett információs és hírközlési technológiák eljuttatása bizonyos régiókba vagy közösségekhez csak a probléma könynyebbik fele. A nehezebbik azoknak az alapvetô szerkezeti változásoknak az elindítása a társadalmi viszonyok terén, amelyek a közösségeket közelebb hozzák a modern világhoz anélkül, hogy ugyanakkor azoknak azonosságtudatát és kulturális folytonosságát aláásnák.

Mivel a változásokkal szemben számos külsố és belsố ellenállást kell leküzdeni, a kulturális folytonosságot megốræố modernizációs stratégia megalkotása valóban egy elcsüggesztően nehéz feladat. Olyannyira, hogy gyakran a pszichológiai tagadás reakcióját 
váltja ki a modernizációs irányelvek elemzőiból és döntéshozóiból, akik a valódi probléma megoldása helyett erôfeszítéseiket technológiai álmegoldások létrehozására fordítják. Semmi sem állhat messzebb a valóságtól mint az a káprázat, hogy pusztán teleházak felállítása a közösség által elérhetô helyeken, melyek számítógépekkel, nyomtatókkal, faxokkal, telefonokkal és (akár gigabites sebességü) Internet-kapcsolattal vannak ellátva, egymagában átlebegteti a közösséget a modern világba.

\section{Alaptétel}

A kemény infrastruktúra átállításának gazdasági és politikai komplexitása ellenére, a puha infrastruktúra átalakulási nehézségei és a kapcsolódó kulturális változások kényszere fogják uralni az átmenetet a társadalmi kapcsolatok most kitáruló, új világába.

Ezért, ha az átalakulás folyamán teleházakat alkalmazunk, akkor létfontosságú, hogy felismerjük a nélkülözô vidéki és városi közösségekben a teleházak alapvetö feladata a kulturális folytonosságot megốrzố modernizáció, amelyben a fejlett információs és hírközlötechnológiák, mint a Gigabit-sárszélességü Internet, katalizáló és segitố sæerepet játsæanak.

Noha a teleházak sikeres müködésének sok olyan vonása van, amely az egyénektöl és a közösségtôl is adaptációt és tanulást követel, tehát széleskörü kulturális változásokat hoz létre a modernizáció irányában ${ }^{76}$, ezeknek a változásoknak nem kell ütközésbe kerülniük a közösség identitástudatával. Az ütközés elkerülhető, ha a szükséges változások iránya, sebessége és mérete a közösség irányítása alatt marad és nem kívülrôl próbálják ráerôszakolni. Ilyen közösségekben a önállóan vezérelt adaptáció, melyet a teleházak tesznek lehetốvé, az eró forrásává, as identitástudat megerósitőjévé válik. Az önálló alkalmaskodási folyamatok egyébként minden jól müködő közösségben a kulturális identitás lényeges forrásai. Ezzel ellentétben, végzetes kulturális összeomlás a fejlódés vagy változások során általában akkor áll eló, amikor külsö beavatkozás próbálja átszervezni a társadalmi kapcsolatokat, vagy amikor közösségek és szervezetek megpróbálják megvetni lábukat, hogy megállitsanak bárminemü változást, és aztán ordítva és rúgkapálva vonszolja óket maga után a történelem sæekere.

\section{A közösségi autonómia szerepe}

Az autonómia egy teleház fennállásának lényeges eleme attól a pillanattól kezdve, amikor a teleház projekt elốször életre kel. Egy korábbi New York-i konferencián ${ }^{77}$, mely a közösségi technológia kérdéseit vitatta, számos olyan amerikai teleház képviselője vett részt amelyek a „közösségi technológiai központ” megnevezés alatt múködnek. Többször is felmerült a kérdés, hogy a központ tevékenységébe hogyan is lehetne belevonni a közösséget? A válasz az, hogy ha egy ilyen probléma egyáltalán felmerül, az azt jelzi, hogy a központ felépítésében valami kezdettől fogva hibás volt. Ilyen kérdés soha sem merül fel az olyan teleházak esetén, amelyek nem jöhettek volna létre anélkül, hogy egy közösség eleve elhatározta volna, hogy jelentôs erốfeszítéssel megvitatja a teleház céljait, megszervezi, létrehozza, és magáénak tekinti azt. Már a „közösségi technológiai központ” név is azt sejteti, hogy a múködés súlypontjának áthelyezése nélkül a technológiáról a közösséget mozgató aktuális kérdésekre, nehéz lesz a „központnak” fenntarthatóan sikeres múködését biztosítani. 
Az autonómia ugyancsak jelentős szerepet játszott azoknak a teleház hálózatoknak a sikerében, amelyeket Nyugat-Ausztrália alacsony népsûrûségú, vidéki területein építettek ki. Egy mostanában készült felmérés szerint az, hogy a teleházak „a közösség tulajdonában vannak, a közösség által irányítottak és a közösség szerves részét alkotják, nemcsak helyes, de olyan eredmények elérését teszik lehetôvé, amelyek nem sikerültek volna egy kormánytulajdonban lévô projekt esetén." ${ }^{78}$ Mégis, az autonómia elérése nem volt önmagától adott annak a rendszernek a keretén belül, amely eredetileg a kötelezô oktatás utáni továbbképzésre fektette a hangsúlyt. „Jelentôs húzódzkodás állt fenn az oktatási minisztérium részérôl, hogy a közösségnek adják a teleházakat, és elveszítsék az irányítást felettük. Heves viták után végül megegyeztek." ${ }^{79}$

Kanadában a kormányzat a CAP (Community Access Program - Közösségi Hozzáférési Program) elindításával tette lehetôvé az 50000 főnél kisebb önkormányzatok számára a hozzáférést a modern informatikai és kommunikációs technológiákhoz. Az Információs és hírközlési technológiák és vidékfejles»tés címû OECD jelentésben idézett elemzés szerint „a CAP egyik nagy ereje az a rugalmasság, amely lehetővé teszi minden egyes közösség számára, hogy az megfeleljen a helyi körülményeknek kihívásainak ... minden CAP projekt megegyezik abban a közös elképzelésben és megértésben, hogy a közösségeknek aktív résztvevőként kell megoldásokat találniuk az információs kor technológiai, gazdasági és társadalmi problémáira." ${ }^{80}$

Az autonómia és az, hogy a teleházat a közösség a magáénak tekinti, valamint a közösségi irányítás kezdettôl fogva áthatották a magyar teleházmozgalmat, ami ma a világon az egyik legsikeresebb kezdeményezés. ${ }^{81} \mathrm{Az}$ utóbbi években sok országban számos hasonló szervezkedés történt, ezek közül a magyar mozgalmat különlegessé teszi az autonóm erőfeszítéseknek, nevezetesen a közösségek egyéneiben gyökerező közösségi erőfeszítéseknek különlegesen nagy mértéke. Ezek közösségrôl közösségre változnak abban, hogy hogyan fogalmazzák meg a teleház célkitûzéseit, honnan gyűjtik össze az elindulási tőkét, milyen vállalkozásokat és egyéb piacorientált kezdeményezéseket hoznak létre, és milyenfajta kormányzati támogatásokat szereznek. Ez utóbbiak nem segélyeket juttatnak, hanem közszolgálati funkciók vállalására kötött szerzôdések formájában fedezik a teleházak múködtetési költségeinek jelentôs részét, sokszor felét.

Nem kétséges, hogy az egyes közösségi teleházak számára jelentős szellemi, technikai és szervezési támogatást biztosít a Magyar Teleház Szövetség. A Szövetség emellett megköveteli tagjaitól hogy bizonyos minimális közszolgálati tevékenységeket elvégezzenek, és a teleházi szolgáltatásokkal kapcsolatban elvár egy megfelelő minôséget. Ettôl függetlenül, minden teleház egy önállóan múködố jogi személy, amely mindenkor közösségének irányítása alatt marad. Ennek a közösségnek egyben a felelőssége is annak az energiának és kezdeményezőkészségnek állandó megújítása, amely a teleház folyamatos múködését és vitalitását kell, hogy biztosítsa.

Alapvetốen fontos, hogy a magyar teleház mozgalom legfóbb célja nem a fizikai hozzáférés biztosítása a számítógépekhez és az Internethez. Még csak nem is a digitális szakadék áthidalása, vagy a számítógépes, internetes múveltség terjesztése, hanem az, hogy a kis vidéki közösségeknek hangot adjon a szélesebb társadalmon belül. Ez jelenti a közösségi támogatást a kormányzattal kapcsolatba lépő egyéneknek (különösen a helyi kormányzattal, amely hajlamos az önkényességre minden történelmi korban); jelenti a közösségi segítséget az üzleti kapcsolatba lépô egyéneknek (foglalkoztatást és távmun- 
kát, kézmûves és turisztikai marketing tevékenységet, üzleti és bedolgozó szerződéseken alapuló kezdeményezéseket és még sok minden mást beleértve); jelenti továbbá a kormányzat azon szolgáltatásainak átvállalását, amelyekben a közösség meg tud egyezni.

Visszatekintve tisztán látható, hogy a magyar teleház-jelenség lényegében egy szolidaritási mozgalom, melynek célja a kis vidéki közösségek és lakosaik hatékonyabb integrálása a civil társadalomba. Abban a mértékben, amelyben ez a cél megvalósul, a teleházak vezetố szerepet töltenek be az átmenetben a jelenlegi szélsôségesen piaci etika oldaláról egy kiegyensúlyozottabb egyéni-közösségi társadalmi etika felé, s annak alapján, egy demokratikusabb mindennapi társadalmi múködés irányában. Bár a számítógépes múveltség terjesztésének technológiai szempontjai és a digitális szakadék áthidalása alá vannak rendelve a társadalmi változás ezen folyamatának, ettốl nem gyengülnek, sốt ellenkezőleg, nagymértékben megerősödnek. Ebben a tekintetben a magyar teleház mozgalom olyan tapasztalatokat halmoz fel, amelyekre égetố szükség van a harmadik világban és egyéb elmaradott régiókban.

Jelenleg a magyar kormányzat annak a nagy tervezetnek az elindításán fáradozik, hogy létrehozza a Közhálót. A Közháló körülbelül kétezer-kétezerötszáz teleház és egyéb, hasonló közfunkciót ellátó intézmény összekapcsolásával jönne létre. Ez része annak az erôfeszítésnek, hogy minden állampolgár számára biztosítsa az Internet elérésének jogát, mint elemi állampolgári jogot. A széles alapokon nyugvó, folyamatban lévố kulturális változások a modernizáció irányában - amelyeket a teleház mozgalom és ennek kiterjesztései már megindítottak - kitúnő kilátásokat biztosítanak a regionális és nemzeti fejlődést támogató GEF hálózatok hatékony kihasználására.

\section{A technológia szerepe és a GEF ígérete}

A fenti állítás közvetlenül visszavezet a jelen elemzés kezdetéhez: hogyan tud hozzájárulni a GEF telepítése a regionális fejlődéshez? Egy látszólagos ellentmondást kell tisztázni ahhoz, hogy megkíséreljünk válaszolni erre a kérdésre.

A technológiai változás és a kulturális változás viszonyát két perspektívából nézhetjük, melyek között ellentét létezik. Az egyik perspektívából, amint fentebb erôsen hangsúlyoztunk, a társadalmak, és az ezeken belül a közösségek kulturális alkalmazkodása a legfốbb problémakör abban a tekintetben, hogy lehetôvé teszik-e a GEF és hasonló fejlett technológiák használatát a saját fejlődésük elősegítésére. Ebből a nézôpontból a kulturális változás irányítja a technológiai haladást, s így a régió fejlődését.

Az ellentétes perspektívából a GEF és az optikai hálózat az, amiben megvan a lehetôség, hogy a kulturális evolúció egy teljesen új szintjét nyissa meg az emberek közötti kapcsolatokban, oly módon, hogy a jövőben a mindenütt jelenlévő optikai hálózatokon nulla határköltséggel válik majd lehetôvé rendkívül nagy adatmennyiségek gyakorlatilag azonnali továbbítása a Föld bármely két lakója közt. Ebból a nézôpontból a technológiában megtestesülő emberi tudás a kulturális változás hajtóereje az egész világon, nem csak egy régióban.

Ez a nyilvánvaló ellentmondás azonban könnyen feloldható egy evolúciós nézôpontból. Az elméleti és alkalmazott tudás növekedésében korszakalkotó technológiai előrelépések lappanganak. Egy megfelelő társadalomban egy bizonyos pillanatban a tudás éretté válik a gyakorlati alkalmazásra. Azok az újítók, akik az új technológiát 
gyakorlatilag felhasználhatóvá teszik - akár a felfedezés régiójában akár másutt - jelentős előnyhöz jutnak, ami a régió fejlődését elősegíti. Eddig úgy látszik, hogy a technológia irányítja a kulturális változásokat.

Mégis megjegyzésre érdemes, hogy egy előzetes kulturális hajlam a technológiai elốnyök elfogadására és gyakorlati megvalósítására kritikus szerepet tölt be, mert nem biztos, hogy az a régió lesz az elsố a megvalósításban, amelyben az elméleti áttörés megtörtént. Az 1940-es és 50-es években számos angol találmányt végül az Egyesült Államokban valósítottak meg. Az előzetes kulturális hajlam kulcsfontossága még világosabb, ha figyelembe vesszük, hogy az új technológiák hogyan, merre és milyen gyorsan terjednek el. Ami számít, az az, hogy meglegyen a hajlam az alkalmazkodásra a változó világhoz, a megjelenố új technológiához.

Ezért, amint a GEF egy létezô, használható technológiaként jelenik meg, csupán az új világhoz alkalmazkodásra, a kreatív kulturális változásra való hajlandóság szabja meg, hogy merre, hogyan, és milyen gyorsan kerül az a helyi fejlôdés használatába. Most tehát a kulturális változás irányítja a technológiai változást.

De ez még nem minden. Vannak esetek, amikor egy új technológia elérhetôsége egy olyan kulturális változást okoz, amely nélküle nem jönne létre, s ez még egy további fordulatot ad az oksági függés folyamatának. Egy hasonló területen szerzett tapasztalat fogja illusztrálni az elképzelést, hogy a technológia segítôje és katalizátora lehet történelmi változásoknak. Az 1960-as évek elején a szerző részt vett egy munkában, amelyet az IBM Yorktown Heights-i kutatólaboratóriuma irányított. Az IBM vállalat tervezési folyamatát kellett számítógépesíteni. A számítógépesítés során szükséges volt olyan szervezeti változtatásokat is végrehatjani, amelyek egyes alkalmazottak viszonylagos befolyás- és tekintélypozícióit érzékenyen érintették. Meglepố módon az derült ki, hogy ezek a változtatások tökéletesen végrehajthatóak lettek volna anélkül, hogy a számítógépeket egyáltalán behozták volna. A változtatások igen hasznosak lettek volna önmagukban is - csakhogy nem lettek volna végrehajtva akkor, és valószínúleg jó sokáig késóbb sem, ha a számítógépesítés folyamata ki nem kényszeríti ôket. Így ennek a hasznos átszervezésnek a hajtóereje fő́ként a rejtett ellentétek feloldásából és szervezeten belüli nem kielégítő megoldások megszüntetésébôl származott. A tervezési folyamat számítógépesítése pusztán katalizálta ezeknek a rejtett energiáknak a szabadra bocsátását. Természetesen, amint beindult a számítógépesítés folyamata, ez hosszabb távon olyan változásokat hozott a vállalati kultúrában, amelyeknek haszna messze meghaladta a kezdeti elônyöket. Tehát ebben a helyzetben ismét a technológia irányította a kulturális változást.

Az IBM esetéhez hasonló dinamika fedezhető fel a korai 1990-es évek magyarországi teleház fejlődésében is. Az információs és kommunikációs technológia (information and communication technology - ICT) katalizátorként múködött a magyarországi teleház mozgalom elindításában. Ez a mozgalom hosszabb távon a kis, vidéki közösségeknek erős, a nemzeti társadalomban visszhangzó hangot adott, és elkezdte megváltoztatni azoknak kormányzati, városi és üzleti kapcsolatait. A változások valódi hajtóereje a tradícionális hatalmi központok és a vidék közötti ellentétekből és feszültségekből származott; mégis, a változások talán a mai napig sem indultak volna meg, ha nincsenek számítógépek és az Internet.

A technológiai- és a kulturális változások fent vázolt összefüggéseiből gyakorlatilag az számít, hogy azoknak az elmaradott régióknak és közösségeknek, amelyek 
szeretnék a GEF új technológiájának a hasznát élvezni, le kell győzniük a kulturális adaptáció nehézségeit, mert ez az adaptáció a GEF hatékony kihasználásának az előfeltétele.

Ott, ahol ezt a kulturális változást a teleházak létesítése már beindította és az folyamatosan halad elôre, a regionális fejlôdés számára a GEF rendkívül sokat ígér.

- A GEF drámai elốrelépés a kemény kommunikációs infrastruktúra terén, de használatának módja, vagy hogy egyáltalán értelmesen használják-e, függ a puha infrastruktúra tulajdonságaitól.

- A teleházak jelenlegi lassú Internet kapcsolatának óriási feljavítása a GEF telepítésével, lehetôvé teszi a weboldalak gyors elérését és a telekonferenciázást. Ennek ellenére, az emberek oktatása a web és a telekonferenciák kezelésére csak egy szerény kezdet marad mindaddig, amíg nincs valós indok a weboldalak használatára, vagy a telekonferenciázást csak az ország másik végén lévő esküvő látogatására használják fel.

- Annak biztosítása, hogy a GEF telepítése a teleházakba átütő hatással legyen a lemaradott közösségeket sújtó digitális megosztottságra, összetett stratégiát igényel, mely szorosan összehangolja a fizikai létesítmények (mint a GEF csatlakozások) létrehozását a puha infrastruktúra fejlesztésével. Ebbe beletartozik:

- az iskolák bővített felelősségvállalása a diákok, és a szülők számítástechnikai továbbképzésében;

- egyre szélesedô munkavállalási kapcsolatok teremtése a közeli ipari és egyéb vállalatokkal, amelyek ki tudják használni a lassan fejlődő digitális képességeket; és

- az elmaradott közösségek kapcsolatainak erôsítése a távolabbi hasonló közösségekkel, illetve a környezô társadalom szélesebb rétegeivel.

- A digitális szakadék áthidalásán túl a teleházak csak akkor felelnek meg alapvetô küldetésüknek, ha integrálják a leszakadt, elmaradott közösségeket a szélesebb nemzeti és esetlegesen a nemzetek feletti civil társadalomba.

\section{ZÁRSZÓ}

\section{Elkötelezettség és rugalmasság a regionális átmenetekben}

Az a Schumpeter-féle kreatív pusztítás, melyet a GEF és a hasonló optikai technológiák visznek elôre, még csak most kezd gyorsulva megindulni. Ebben a helyzetben milyen alapokon kell lerakni az ésszerú regionális fejlődés irányelveit, amelyek figyelembe veszik az alternatív technológiai megoldásokat, különösen azokban a régiókban, melyek nincsenek a technológiai és gazdasági fejlődés élvonalában?

Legelőször is a hírközlési technológia, bár hoz is kulturális hatásokat, meg maga is ki van téve azok következményeinek, gyakorlatilag nem lehet a modernizáció és az élenjáró régiókkal való felzárkózás kulturális átalakulásainak hajtóereje. Ellenben mégis olyan katalizátori szerepet tölthet be, amely lehetôvé teszi a társadalom számára, hogy szembeszálljon azokkal a feszültségekkel, ellentétekkel és dualizmusokkal, amelyek gátolják az alkotó fejlődést. A regionális fejlődés irányelveiben a hangsúlyt a tár- 
sadalmi kapcsolatok puha infrastruktúrájának fejlesztésére kell helyezni, párhuzamosan az új technológiák kemény infrastruktúrájának bevezetésével.

Másodszor egy régió nemzetközi versenyképessége megköveteli azt, hogy a fejlődés meg ne rekedjen az elavult, kilátástalan technológiák csapdáiban. Ezért a GEF telepítésére való komoly elkötelezettség, még inkább annak befogadásában és kihasználásában vezetôi szerep vállalása, egy nagy ígéretû stratégia a régió versenyképességének növelésére.

Harmadszor, mindemellett egy ilyesfajta komoly elkötelezettségnek nem szabad vakhitnek lennie. A rugalmasságot meg kell ôrizni, mert abban az esetben is, ha egy új technológiát már bevezettek máshol, az mégis technikai és intézményi alkalmazkodást igényel, hogy gond nélkül lehessen használni. Még ha már múködik is az új technológia, akkor is nyíltnak kell lenni az alternatív lehetôségekre, mert néhány év alatt minden újat felülmúlhat egy még újabb; vagy pedig egy jelenleg másodrangú hatékonyságú technológia a gazdasági vagy társadalmi változások hatására az élre törhet. Ez igaz a GEF-re és a többi optikai technológiára is, annak ellenére, hogy a telepített optikai szál magas valószínúséggel idôtálló befektetés lesz, legalábbis a következő két évtizedre. Konkrétabban, az elkötelezett, de megfontolt átmenet a régi telekommunikációs és kábeltechnológiákról a GEF-re, elegendő lehetőséget biztosít a rugalmasság megốrzésére.

Számos régió most teszi első lépéseit az univerzális, világot befogó, Gigabit-sávszélességű Internet felé. Az egyes régiók fejlődésbeli előnyein túl, ez elmozdulást jelent a történelmi evolúció újabb, magasabb szintjére. A társadalmi kommunikáció alapvetố változásai, melyek mindig materiális és kulturális vonásaiknak egységében jelentek meg, sorozatosan új és tágasabb világokra nyitottak kaput az emberiségnek. Kezdve magával a nyelvvel, a tárgyak, az idô és a számok absztrakt képi ábrázolásán keresztül; a képíráson, a szótagíráson és a betưíráson át; folytatva a nyomtatással, a távíróval, a telefonnal és a számítógéppel; és végül elérve az alacsony sávszélességű, majd az optikai Gigabit-sávszélességû́ Internetet, minden új szint egy új dimenziót ad ahhoz, hogy mit jelent embernek lenni.

Nem láthatjuk át, sôt még bizonytalanul sem körvonalazhatjuk, hogy mi van azokon a kapukon túl, melyeket a végponttól végpontig tartó optikai szélessávú hálózatok éppen most tárnak fel nekünk. Ha azonban szeretnénk valamit hozzáadni az átgondolt irányelvekhez, amelyek befolyásolják azoknak a régióknak a fejlődését, amelyeknek jövőjével azonosulunk, akkor meg kell, hogy értsük, hogy példa nélkül álló dolog felé haladunk. Egy minôségileg új szintet sejtünk emberi világunk kitárulkozásában. Ugyanekkor el kell fogadnunk azt az egzisztenciális tényt, hogy a társadalmi kommunikáció folyamatának materiális és kulturális alapjai csak akkor hozhatnak emberileg jelentôs változást, hogy ha azok egymással lépést tartva változnak meg. 


\section{FÜGGELÉK: REGIONÁLIS GEF TELEPÍTÉSEK}

\section{Létező telepítések}

Megadott területeken tervezett GEF telepítésekkel kapcsolatban nagyon hasznos volna, ha kéznél lenne egy megbízható összehasonlító felmérés a létező regionális GEF telepítésekrôl. Ennek a cikknek szempontjából a legnagyobb érdeklődéssel kísért telepítések a középszintú hálózatok, amelyek összekötik az iskolákat, kórházakat, egyetemeket és önkormányzatokat; amelyek képesek további terjeszkedésre vagy horizontális összekapcsolódásra más hálózatokkal; amelyek összekapcsolódnak a magasabb szintû országos és nemzetközi hálózatokkal; és amelyek megfelelő csatlakozási pontokat biztosítanak az alacsonyabb szintû helyi hálózatok révén a háztartások és kisebb vállalkozások elérésére.

Sajnos ilyen felmérés nem létezik. Továbbá az ebben a cikkben megemlített GEF telepítések közül csak kevés van jól dokumentálva. A Community Condo Fiber Networks - The Customer Empowered Networking Revolution (2002) címú írás a legjobbak között van. Technikai részleteket közöl számos kanadai önkormányzat általános iskoláit összekötố hálózatokról, emellett tájékoztat a megépítéshez szükséges összegekről és ezek gyors megtérülésérôl, az új hálózatok által elért megtakarítások révén. Számos más telepítés dokumentációját össze kell még állítani személyes interjúk és nem publikált háttéranyagok alapján. Alan McAdams, a Cornell Egyetem Johnson Graduate School of Management tanára és diákjai most kezdtek el egy ilyen munkát két iskolai hálózat esetében (Broome-Tioga és SCT BOCES) ${ }^{82}$, amelyek New York állam északi részén helyezkednek el. Ezeket háttéranyagként bemutatták az IEEEUSA washingtoni, szélessávú hálózatokat megvitató múhelyén (2002. június 17-18).

Eltekintve azoktól a telepítésektôl, amelyek weboldalát korábban említettük, egy internetes keresés a „gigabit ethernet regional deployment” kifejezésre, vagy hasonló keresési feltételek esetén, az elốkerülő weboldalak nagy része a következô három kategória egyikébe esik:

- Sok közülük vállalkozások reklámcéljait szolgálja és a fejlesztésben való részvételt, illetve eszközöket kínál.

- Egy másik nagy kategória a nagyvállalatok belsố kommunikációjához épített magánhálózatokat fedi.

- A harmadik kategória az egyetemeknél felállított hálózatokat tartalmazza.

Két fontos felmérés létezik a hálózatokról Európában, de egyik sem lényegesen használható a fent részletezett szempontok szerint.

TERENA (Trans-European Research and Education Networking Association: Transz-európai Oktatási és Kutatási Hálózatok Egyesülete) mostanában jelentetett meg egy kivonatot, amely a nemzeti oktatási és kutatási hálózatokról (national research and educational networks - NRENs) szól. Ez a felmérés ${ }^{83}$ tartalmaz olyan összefoglaló táblázatokat, amelyekben látható minden egyes európai ország esetén azon intézmények száma, amelyek állandó kapcsolattal rendelkeznek: (1) közvetlenül az NREN egy pontjához, (2) az NREN által menedzselt regionális vagy nagyvárosi hálózaton keresztül, (3) harmadik fél által múködtetett regionális vagy nagyvárosi hálózaton keresztül, avagy (4) más módon. A táblázatok emellett megadják az alaphálózat által használt technológiát és a következő két évben tervezett technikai változtatáso- 
kat. Az alaphálózaton Gigabit Ethernetet jelenleg négy ország esetében említenek, és bevezetését még egy ország tervezi. A többi ország esetében az alaphálózat a legtöbb esetben valamilyen más szélessávú optikai technológia, mint például az ATM vagy a SONET.

A TERENA táblázatokból viszont nem derül ki, hogy a végfelhasználók milyen sebességgel kommunikálnak, hiszen ez különbözik az alaphálózat sebességétôl, és a táblázatok nem tartalmaznak részletes adatokat a regionális és nagyvárosi hálózatok technológiájáról és sebességéról sem, pedig ezeken a hálózatokon keresztül számos felhasználó kapcsolódik a NREN hálózathoz.

Tizenöt tagállamot lefedő hálózati felmérések újabb hétrészes sorozatát indította el és adta ki a European Survey of Information Society, amely projektet 1997-ben indította el az ISPO, az Information Society Promotion Office of the European Commission. ${ }^{84} \mathrm{Az}$ ESIS 2 egy sokkal frissebb jelentés, 25 államra terjed ki Közép- és Kelet-Európában, illetve a mediterrán térségben.

$\mathrm{Az}$ eredeti ESIS adatai sajnos már több mint négy éve elavultak; a saját weboldaluk már 1999. január 1-je óta nem volt frissítve. A sokkal frissebb ESIS weboldalon ${ }^{85}$ elérhetố projektekrốl szóló összefoglalások túlságosan szúkszavúan szólnak a technológiai specifikációkról. Csak 10 kategória van, amelyek közül az „Intranetek, extranetek és más IP alapú hálózatok” áll a legközelebb a GEF-hez vagy más, végponttól végpontig terjedô optikai technológiához. Továbbá az információ nem áttekinthető́ ha keresünk valamit, akkor projektrôl projektre át kell nézni.

Legalább egy európai kutatóintézet tervez jelenleg a korábban említetthez hasonló felmérést, amelynek célja a középszintû regionális és nagyvárosi hálózatok tanulmányozása. Ha egy ilyen törekvés elindulna, komoly figyelmet érdemel finanszírozó szervezetek részéról.

\section{Kihívások és kutatási feladatok}

Két közvetlen kihívást figyelhetünk meg a GEF telepítéssel kapcsolatban. Mind a kettố a puha infrastruktúra átalakulásával összefüggó probléma.

Az első kihívás kapcsolatos azokkal a fejlett nagyvárosi régiókban lévő területekkel, amelyeken nagy a nyomor és ugyanekkor gyakran koncentrálódnak etnikai, faji vagy vallási kisebbségek. Az ezeken a területeken általában uralkodó magas népsûrúség körülményei között a feltűnően eltérô kulturális jellegzetességekkel bíró népcsoportok nem feltétlenül különülnek el földrajzilag, hanem gyakran átfedik egymást, még akár egy háztömbön belül is. Ez sokkal nehezebbé teszi a közösségi identitás és autonómia kibontakozását, mint a földrajzilag jól körülhatárolható vidéki közösségekben. Az ilyen bonyolult körülmények között létrehozott teleházak gyakran sikertelenül próbálják bevonni a közösséget.

A másik kihívás a Harmadik Világ. Ez a cikk fóleg azokkal a problémákkal foglalkozott, amelyek olyan elmaradott régiók estén merültek fel, ahol már volt elfogadható kommunikációs infrastruktúra és a környezố területek a fejlett vagy a meglehetôsen fejlett kategóriába tartoztak, tehát a hangsúly Európán és Észak-Amerikán volt. A Harmadik Világ problémái egy más nagyságrendbe tartoznak. Az elfogadható, hogy ezen cikk elképzeléseit elmaradott vagy elzárt falusi közösségekre, illetve problémás 
városi területekre alkalmazzuk Európában vagy Észak-Amerikában. Teljesen más a helyzet viszont a India vidéki területein, ahol a makacsul kitartó nemek és kasztok közötti egyenlőtlenségek mélyen gyökereznek az emberekben még a legösszetartóbb kis falusi közösségekben is, vagy a délkelet-mexikói maja falusiak esetében, akik durva beavatkozásnak értékelnek bármely, kintrôl jövố kezdeményezést, amely önálló, a közösség által irányított változásokat remél előmozdítani.

Mind a két fenti kihívás esetén az a feladat, hogy megállapítsuk a feltételeket, amelyeknek közepette a megfelelô változtatások a puha infrastruktúrában létrejöhetnek, valószínúleg egy kölcsönhatás viszonyrendszerében, mely a GEF, az Internet és a számítógépek által nyújtott lehetőségek megragadása révén alakul ki.

Mindamellett meg kell jegyezni, hogy mind a két kihívásnak van egy olyan aspektusa, amely nem került szóba a puha infrastruktúra és a kulturális változás kapcsán. Ez a hatalom dimenziója, az elválaszthatatlan gazdasági és szociális igazságtalanságoké, amely mindig fellelhetô az Elsô Világ városi nyomorában és a Harmadik Világ fejletlenségében. A teleházak legjelentôsebb kritikusa, Gamucio Dagrón ezt tartja azon helyzet kialakulásáért felelősnek, aminek eredményeképpen „minden száz teleház közül csak egy van olyan, amelyik a fejlődés támogatását és a társadalmi változást tekintve... igazán hasznos a közösség számára" ${ }^{86}$ A két kihívásra nincs egyszerû válasz: jusson eszünkbe, hogy a sikeres ókori rabszolgalázadások végül mindig visszaestek ugyanazokba a régi úr-szolga viszonyokba (csak új arcokkal), vagy az, hogy a sikeres huszadik századi szocialista forradalmak szintén visszaestek ugyanazokba a régi gazdag-szegény viszonyokba (hasonlóképpen új arcokkal).

A leendő GEF telepítésekkel kapcsolatban minden bizonnyal a legfontosabb és egyben legbonyolultabb kihívás a technológiai fejlődés és a kulturális változás kölcsönhatásába bepillantást nyerni mind elméleti, mind gyakorlati síkon, a hatalmi viszonyok megfelelő szemléletével. „A technológia szerepe és a GEF ígérete” címú korábbi fejezet éppen csak, hogy érintette ezt a témát.

Hogy mi a teendô, azt talán a következố négy feladat segíthetné értelmezni: először is, a technológia szemléletében kell változásnak beállnia - át kell állnunk a technológia műszakibb szemléletéről a klasszikus és még mindig sokkal mélyebb szemléletre, amely szerint a termelési erók lényege az emberi erôfeszítésekben áll, melyeknek mind biológiai-evolúciós, mind társadalmi-történelmi távlatú alapjai is vannak; másodszor, fel kell frissíteni a termelési erók fogalmát az emberi tudás felhalmozására összpontosítva, amely egyrészt az anyagi világban történố túlélésre, másrészt pedig a társadalomban az életminôség javítására van alkalmazva; harmadszor, hasonlóképpen mélyíteni kell a kultúra változásáról alkotott, jelenleg „összehasonlító statikus” (tehát nem dinamikus) képet, visszatérve a termelési viszonyok klasszikus nézetéhez, amely magában foglalja a hatalmat is, de ezt frissíteni kell az irracionalitással és a destruktív és öndestrutív egyéni avagy társas viselkedéssel kapcsolatos legfrissebb pszichológiai és társadalmi meglátásokkal; és végül elemzést kell adnunk a történelmi változás két fenti nézốpontja - az emberi tudás és az emberi kapcsolatok - közti kölcsönhatásról, amelyet a jövőbe haladó, integrált totalitásként kell kezelni.

$$
\begin{aligned}
& \text { Kozma Andrea forditása } \\
& \text { A szerzó lektorálásával }
\end{aligned}
$$




\section{JEGYZETEK}

${ }^{1}$ A városi és területi tervezés rendkívüli tanára (Cornell University, Ithaca, NY), a városi tervezés rendkívüli tanára (Columbia University, New York City), a közgazdaságtan nyugalmazott professzora (New School University, New York City)

2 Ez a cikk a 2002. június 17-18-án Washington D.C.-ben megtartott, az USA-beli szélessávú hálózati telepítések felgyorsításának nemzeti irányelveit vizsgáló múhely számára (IEEEUSA Workshop On U.S. National Policy for Accelerating Broadband Deployment) készített jegyzetanyag átdolgozott és kibővített változata. A szerző a Cornell Egyetem munkacsoportjának tagjaként részt vett az IEEE-USA-val együtt a múhely előkészítésében és az ott készült eredmények és következtetések végső megfogalmazásában. Sok köszönet illeti meg az átdolgozott vázlathoz nyújtott fontos segítségéért, aminek eredménye a cikkben felhasználásra került, Robert Proulx-t és François Ménard-ot a XIT Telecom-tól; François-t a revízióiért és a megjegyzéseiért is, és Alan McAdamset a Cornell Egyetemről a kéthetenként tartott intenzív megbeszélésekért és az azokkal együttjáró ötletbörzéért, amely érintette az itt megvitatott és egyéb, az Internettel összefüggố problémákat, egészen a nyolcvanas évekig visszamenőleg.

${ }^{3}$ A cikk témája a GEF körül forog. A szerzố tudatában van annak, hogy az optikai szélessávú hálózatok technológiája folyamatosan fejlódik és a jövốben a GEF-et más technikák válthatják fel, mint preferált lehetőségek. Léteznek alternatív hálószerkezetek, amelyeknek hasonló a hatékonyságuk és költségjellemzőjük, de kevésbbé elterjedtek a piacon, mint például a passzív optikai hálózatok (PON = passive optical networks) és a fordított passzív optikai hálózatok $(\mathrm{RPON}=$ reverse passive optical networks). A legalapvetóbb vitapont a Gigabit-sávszélességú internetes optikai földi vonalak kérdése, amelyek a legkedvezőbb rendelkezésre álló technikai lehetôségeket aknázzák ki.

${ }^{4}$ A továbbiakban felváltva szerepel az adatátviteli sebesség és a sávszélesség kifejezés. A sávszélesség egy adatátviteli csatornán rendelkezésre álló adatátviteli kapacitás. Ez arányos a teljes adatátviteli sebességgel, hacsak nincs a csatorna alcsatornákra osztva, amikor ez az arányosság már nem áll. Mikor alcsatornákról nincs kifejezetten szó, a két fogalom azonosítása nem ad félreértésre alkalmat. (A Ford.) A digitális hangot vagy adatot továbbító, rézból készült telefonvonalak sebessége 62,5 kilobit/másodperc alatt van. (névlegesen 64 kilobit/másodperc, ám a gyakorlatban ennél mindig - sokszor lényegesen - alacsonyabb - a szerk.) A jelenleg legolcsóbb optikai szálas rendszerek, amelyek készen kapható optikai gigabites Ethernet komponenseket használnak, 1 gigabit/másodperc szabvány szerinti átlagsebességgel dolgoznak, ami a gyakorlatban általában egy kevéssel magasabb. A kábel és a DSL elméletben gyorsabb 1Mbps-nál, de a szerző kábelmodemje Manhattan déli részén 200 Kbps alatt múködik.

5 A kifejezés az ausztriai születésú közgazdász után kapta a nevét, aki azt vizsgálta, hogy a kapitalizmus fő fejlesztései nem a keresleti és kínálati feltételek marginális eltolódásai, hanem forradalmi újítások során jöttek létre, amelyek a kínálat, szolgáltatások, termékek és szervezetek új világát hozták létre, a régi lerombolásával. Lásd Schumpeter (1975).

${ }^{6}$ Lásd Mambretti (1999).

7 Lásd St. Arnaud (2001a) „eScience”. Egyéb G-sáv alapú technikai újdonságokról lásd szintén tôle: The Third Wave.

8 Lásd Vanderbilt (2002).

9 Van Eijkelenborg et al (2001).

${ }^{10}$ Yavlonovic (2001). 
"Ez egy új technológia, amely azon a felismerésen alapszik, hogy egy adott helyen és egy adott napon a weboldalak $80 \%$-ának látogatása egybeesik. Így a mủholdas kapcsolat azért szükséges, hogy a napi új anyagot - körülbelül $5 \mathrm{~Gb} /$ nap - le lehessen tölteni. A nagy gyakorisággal látogatott weboldalt a merevlemez eltárolja, így annak letöltése a Kbit-adatátviteli sebességû hálózatot nem terheli, és a fôbb weboldalak hozzáférési sebessége is megnő. (személyes közlés).

${ }^{12}$ Lásd St. Arnaud (2001) Community Condo Fiber, ppt 4; Bjerring and St. Arnaud (2001) The Coming Revolution; Canarie, Inc. (2001) Gigabit Internet; Canarie, Inc. (2002); Canet4; Canarie, Inc. (2002c) „A Nation Goes Online.”

${ }^{13}$ Canarie (2002c) „A Nation Goes Online”, p. 127.

${ }^{14} \mathrm{Ez}$ a bonyolultság abból adódik, hogy a hagyományos telefonhálózatok esetében a kapcsolóés vezérlố összeköttetések párhuzamosan futnak magát a telekommunikációs forgalmat bonyolító vonalakkal. A Kbit sebesség esetében ez az összetettség szükséges ahhoz, hogy a hangszolgáltatás minőségét biztosítsa. A Gigabit sebességnél viszont az Interneten át továbbított hang minôsége alapvetốen enélkül az összetettség nélkül is ugyanolyan, feltéve, hogy létezik nagy tartalékkapacitás. Errôl bővebben késốbb.

${ }^{15}$ St. Arnaud-val az IEEE-USA múhely anyagának revíziója kapcsán folytatott magánbeszélgetés alapján.

${ }^{16}$ Elvben ez az egyetlen visszajelzés, ami a hálózat múködéséhez szükséges. A gyakorlatban apróbb finomítások, amelyek fékezik a torlódást a hálózati csomópontokban, csökkentik a csomagveszteséget és javítják a hatékonyságot.

${ }^{17}$ Cook-jelentés (2002), p.7:”...csomagkapcsolt szolgáltatást támogató költséges infrastruktúra, amely szolgáltatásokat mások is el tudnak látni olyan infrastruktúrával, ami hozzávetólegesen a 10\%-ába kerül annak, mint amit erre a beágyazott helyi telefontársaságoknak (ILEC = incumbent local exchange carriers) kell költeniük."

${ }^{18}$ Lásd Canarie, Inc. (2002) Canet4, > Connectivity > Connected Institutions Map, http://www.canarie.ca/canet4/connected/canet4_map.html .

${ }^{19}$ Lásd St. Arnaud (2001) „Community Condo Fiber”. Itt több példa található Kanada különbözố részeiból és Chicagoból. Albertával kapcsolatban, lásd még Finley (1999), NETERA Alliance (2002); Quebecrôl lásd Proulx (1999), RISQ (2002) Réseau d'Études; és Canarie, Inc. (2002b), Doing IT for the Regions.

${ }^{20}$ Lásd Swedish ICT Commission (2000, 2001), Stockholm Stad (2000); Netnod (2002); és http://www.itkommissionen.se

${ }^{21}$ Dynamic City (2002), World Wide Packets (2002); Schweikhardt (1999).

${ }_{22}$ Palo Alto Fiber Network (2002); City of Palo Alto, CA (2002); Poulton (1999).

${ }^{23}$ Talán a legjobb, jól szerkesztett tényanyag a GEF-rôl és az optikai szálas hálózatokról általában: St.Arnaud (2002) Frequently Asked Questions about Fiber Networks. Ezt a forrást idôszakosan újítják.

${ }^{24}$ Ez a számadat a korábban már említett Bill St. Arnaud-val folytatott magánbeszélgetésből származik.

${ }^{25}$ Cornell University (2002) The Broome-Tioga Boces Regional Telecommunication Infrastructure. Abstract.

${ }^{26}$ Kanada szándékosan támogatja a nagy sávszélesség-igényú szolgáltatásokra irányuló kutatásokat és fejlesztéseket, lásd Canarie, Inc (2001a) Filling the Pipe.

${ }^{27}$ Személyes beszélgetés, François Ménard, XIT Telecom.

${ }^{28}$ FORBES ASAP (2001). 
${ }^{29}$ St. Arnaud (2001) Community Condo Fiber; SECOR (2001).

${ }^{30}$ Személyes beszélgetés, François Ménard, XIT Telecom.

${ }^{31}$ Cook-jelentés (2002). Errol bôvebben az IEEE-USA dokumentációjában megjelent egyéb anyagokban.

${ }^{32}$ Precursor Group (2002).

${ }^{33}$ Isenberg széles körben ismert írása, The Paradox of the Best Network, a késốbbiekben kerül még felhasználásra. David Isenberg reagálása a Googin interjúra a Cook-jelentésben (2002) p. 25.

${ }^{34}$ David Isenberg megjegyzése a Googin interjúra a Cook-jelentésben (2002) p. 25.

${ }^{35}$ Ibid.

${ }^{36}$ Elvben a kábelmodemek valamivel gyorsabbak, mint a DSL, bár közel sincsenek az optikai szálas Gigabit-sebességekhez. De a gyakorlatban a kábelhurkok teljesítménye meredeken zuhan, ha túl sok modem elôfizetố van rákötve, ami a jelenlegi kábelhelyzetnél igen gyakran előfordul.

${ }^{37}$ Cook-jelentés, p. 14 (Googin), p.25 (Isenberg).

${ }^{38}$ Lásd OECD (2001).

${ }^{39}$ Európai Unió, Európai Közösségek Bizottsága (2002) eEurope 2005, p.18.

${ }^{40}$ Dualizmus akkor jelentkezik, amikor egy változó - például az egyének digitális kompetencia-szintje - különböző értékeinek mérési adatai az intervallum mindkét végén összegyúlnek, a középen kevesebb mérési adattal. Ezért például a digitális szakadék azt jelenti, hogy egy-egy személy nagy eséllyel tartozik a magas digitális kompetenciával, vagy más esetben az alacsony, vagy zérus digitális kompetenciával rendelkezố csoporthoz, és hogy aránylag kevés ember van a köztes szinten. Matematikailag ez abban áll, hogy amikor dualizmus jelentkezik, akkor a megfigyelt változó különböző értékeinek a megoszlási gyakorisága két csúcsot mutat egy helyett. Tehát egy összefüggó megfigyelés-halmaz helyett azt a tendenciát tapasztaljuk, hogy az inkább két alhalmazra oszlik - innen a „dualizmus” kifejezés - feltúnốen különbözó jellemzókkel.

${ }^{41}$ Kanadával kapcsolatban lásd a bibliográfia „Kanada és az USA” részét, főleg Bjerring és St. Arnaud (2001) és St. Arnaud (2001) Community Condo Fiber. Svédországgal kapcsolatban lásd a bibliográfia „Európa” részét, fóleg a Swedish ICT Commission $(2000,2001)$, Stockholm Stad (2000), OECD (2001); Netnod (2002); és McKinsey (2002).

${ }^{42}$ A változás velejáró lassúságáról és ezeknek a kulturális értékeknek az utánzási nehézségérôl lásd Storper (1997). Prahalad és Hamel lényegében ugyanígy érvel a beágyazódott szervezeti kultúra tekintetében, ami olyan vállatoknál figyelhetô meg, amelyek jól kialakult alapvetố hozzáértéssel (core competence) rendelkeznek. Ez a hozzáértés a különböző technikai beállítottságú és különböző képességû́ egyénekbôl szorosan összefonódott termelő csoportokat (teams) hoz létre.

${ }^{43}$ Storper, op. cit.

${ }^{44}$ Ibid.

${ }^{45}$ Lessig (2000), (2001). Lessig az „információs közterület” metaforáját az archaikus angol falusi köztulajdonban tartott legelők és egyéb közösségi földek gyakorlatából merítette, amely Amerika északkeleti részeire is áthatott, így például az egyik nagyobb Boston városi park neve mindmáig „Boston Common” maradt.

${ }^{46}$ Ennek a gondolatnak a világos megfogalmazását François Ménard-ral folytatott személyes beszélgetésnek köszönhetem.

${ }^{47}$ A GEF telepítést kiegészítő kemény infrastruktúrára tekintetében a jelen fejtegetés ÉszakAmerikára és Európára összpontosít, ahol már létezik az optikai kábeles szupersztráda, de rö- 
viddel a végsố felhasználó elốtt leáll, és ahol a legtöbb területet egy vagy több telefontársaság fedi le. A Harmadik Világban a GEF telepítése nem szükségképen az elsố feladat; itt a drótnélküli hálózat jelenthet fontos átmeneti lehetőséget. Azonban a réz-és a koaxiális kábelberuházások, amik egy halódó technológiát képviselnek, lehetôleg elkerülendốk.

${ }^{48}$ Jelenleg az alkalmazások egy teljesen új generációja jön létre a G-sávú optikai Internet hatására. Lásd St. Arnaud (2002b) The Third Wave.

${ }^{49}$ Lásd Cifra Médical, Inc. (2002) The Doctor is On-line, in Canarie, Inc. (2002d) Shaping the future, p.7.

${ }^{50}$ Konkrét példákkal szolgál St. Arnaud (2001) Community Condo Fiber; és St. Arnaud (2000) Gigabit Internet to Every Canadian School. Lásd még SECOR (2001) és St. Arnaud (2002) Frequently Asked Questions.

${ }^{51}$ Lásd például Canarie, Inc. (2002a) Remote gall-bladder operation; vagy Cifra Médical, Inc. (2002) The Doctor is On-line, in Canarie, Inc. (2002d) Shaping the future, p.7. Több dokumentált példával szolgál St. Arnaud (2001) Community Condo Fiber.

${ }_{52}$ Több dokumentált példával szolgál St. Arnaud (2001) Community Condo Fiber.

${ }^{33}$ Lásd Itbusiness.ca (2002), St. Arnaud (2001a) e-Science, és St. Arnaud (2002b) The Third Wave.

${ }^{54}$ Lásd a téma korábbi megvitatását a „Közelgő Forradalom” részben.

${ }^{55}$ http://web.icq.com/

${ }^{56}$ Lásd Isenberg (1997, (1998), (2001).

${ }^{57}$ FORBES ASAP (2001).

${ }^{58}$ Lessig, op. cit.

${ }^{59}$ Lásd IEEE-USA (2002, 2002a). A jelentés végleges, hivatalos szövege még nem áll rendelkezésre, de csak stílusszépítések várhatók. Lényeges érdemi változtatások már nagyon valószínútlenek.

${ }^{60}$ IEEE-USA (2002), p.5.

${ }^{61}$ Op. cit. p.6.

${ }^{62}$ A GEF rendszerintegrátor összeköti a helyi csomópontokat (amelyekből az optikai kábel az egyéni végfelhasználókhoz jut el), s amelyekre a legkisebb városi és regionális területi hálózatok kivételével mindenütt szükség van.

${ }^{63}$ Op. cit. p.7-8.

${ }^{64}$ Lásd a bibliográfia USA-val és Kanadával kapcsolatos részeit, fôleg a korábban már idézett forrásokat.

${ }^{65}$ Míg a jelen értekezés a GEF-et használta a jelenlegi legjobb szélessávú optikai hálózatok (lásd Bevezetés) átfogó elnevezéseként, fontos megjegyeznünk, hogy a kanadai gerinchálózat nem GEF és nem végfelhasználó tulajdonában áll. Ez egy előfizetett szolgáltatás, amely a SONET-re épült és a GT-tôl, ill. a Bigpipe-tól bérlik.

${ }^{66}$ Lásd City of Kamloops, BC (2002) Kanadában. Európában Svédország volt a kábelhálózatok lakóépületbe történố telepítésének az úttörôje, Stockholmban (lásd a korábbi hivatkozásokat). Az USA esetében már említettük Palo Altot, CA és Spokanet, WA (Grant County).

${ }^{67}$ Ennek az igénye szintén a 2002. júniusi IEEE-USA Broadband Workshop: IEEE-USA (2002) következtetései közt van. Eddig még nem volt példa Kanadában az optikai kábelek csatornás telepítésére - jelenleg a légvezetékes telepítésű üvegszál az elfogadott technológia.

${ }^{68}$ Lásd St. Arnaud (2002) Frequently Asked Questions, Item 32.

${ }^{69} \mathrm{Az}$ ebben a részben található értekezésnek sok fontos nézôpontja a Robert Proulx-lal (XIT Telecom) folytatott magánbeszélgetésekből származik. 
${ }^{70} \mathrm{Az}$ RISQ (Réseau d'Infomations Scientifiques du Québec) hálózat kiépítésének kezdeti szakaszában Quebecben a helyi vezető telekommunikációs cég kétszer is lebontotta a hálózat egy részét, azt állítván, hogy annak kiépítése illegális volt. Végül a kompetens szabályozó hatóság szigorú fellépése védte meg a telepítést. Személyes beszélgetés, Robert Proulx, XIT Telecom.

${ }^{71}$ Forrás: lásd az előző lábjegyzetet.

72 Lásd a „Közelgố forradalom” részt.

${ }^{73}$ A GEF és a jelenleg létező hagyományos hálózatok kölcsönhatásáról lásd Denton és Menard (2001).

${ }^{74}$ Lásd Canarie, Inc. (2001)

${ }^{75}$ Lásd a „Telecenter” részt a bibliográfiában, főleg az OECD országaira vonatkozó felméréseket - OECD (2001a), Latchem(2001) és a The Journal of Development Communication (2001).

${ }^{76}$ Ahogy mutatják azok a példák, amelyek a modern világhoz való alkalmazkodás sikeres és sikertelen kísérleteit örökítik meg: a bennszülött amerikai és egyéb törzsi kultúráktól a CapeCod félsziget halászfalvaiig, amelyet az 1920-30-as években az új automobilos turizmus rohant le Bostontól Providence-ig.

${ }^{77}$ New York City Community Technology Symposium, 2002 október 24., Columbia University.

${ }^{78}$ Short (2001), p. 39.

${ }^{79}$ Ibid., p.43.

${ }^{80}$ OECD (2001a), p.44.

${ }^{81}$ A 2002-es év végéig majdnem ötszáz vidéki teleház múködött ebben a tízmilliós országban. Ez azt jelenti, hogy minden, 3000 fốnél kisebb lakosságú öt település közül egyben volt teleház. A teleházak gyakorisága vidéken kivételesen magas: minden település max. 10-25 kmre van olyan helytől, ahol van teleház. Lásd a bibliográfia „Teleházak” részét, főleg Gáspár (2001), (2001a), ITU (2001), Demnet (2002), BEEP (2002), Korányi (2002), Larsson (2002), és Latchem et al. (2001).

${ }^{82}$ Cornell $(2002,2002 a)$.

83 TERENA (2002).

${ }^{84}$ ESIS (1999).

${ }^{85}$ ESIS (1999).

${ }^{86}$ Gamucio Dagrón (2001), p.86.

\section{IRODALOM}

Általános

Isenberg, David (1997): Rise of the Stupid Network. a hálón: Entropy Gradient Reversals, http://www.rageboy.com/stupidnet.html

Isenberg, David (1998): The Dawn of the Stupid Network, ACM Networker 2.1, February-March, pp. 24-31. http://www.isen.com/papers/Dawnstupid.html

Isenberg, David, \& Weinberger, David (2001): The Paradox of the Best Network. Draft, Nov 9. http://netparadox.com

Lessig, Lawrence (2000): The Future of Ideas: The Fate of the Commons in a Connected World 
Lessig, Lawrence (2001): The Internet Under Siege. Foreign Policy, Nov-Dec.

Prahalad, C. K. \& Hamel, Gary (1990): „The Core Competence of the Corporation,” Harvard Business Review, May-June, 80-91.

Schumpeter, Joseph A. (1975): Capitalism, Socialism, and Democracy. New York: Harper; els_kiadás: 1942.

Storper, Michael (1977): The Regional World: Territorial Development in a Global Economy. New York, The Guilford Press.

van Eijkelenborg, Martijn A., Maryanne C. J. Large, Alexander Argyros, Joseph Zagari, Steven Manos, Nader A. Issa, Ian Bassett, Simon Fleming, Ross C. McPhedran, G.Martijn de Sterke and Nicolae A.P. Nicorovici (2001).: Microstructured polymer optical fibre. Optics Express 319, Vol. 9, No. 724 September, Optical Society of America (OSA)

Vanderbilt, Tom (2002): Walker in the Wireless City. New York Times, November 24. http://www.nytimes.com/2002/11/24/nyregion/24FEAT.html

Yavlonovitch, Eli (2001): Photonic Crystals: Semiconductors of Light. Scientific American, December, 46-55. (Optikai kábelek: kétdimenziós nyílással rendelkez_anyag elnyújtva a harmadik dimenzió irányában. Korai változatok kereskedelmi forgalomban www.blazephotonics.com Bath-ban (UK) és www.crstal-fibre.com Dániában. „Az egyik változatban a fény a szál közepén lévố lyukon keresztül halad, a körülötte lévő anyag kétdimenziós nyílásával elzárva. Több optikai erốt lehet az ilyen központi nyíláson átküldeni, mint az üvegen át, így a hagyományos telekommunikációs kábeleknél akár százszor nagyobb információ-átvivô kapacitást érhetünk el."

Kanada és USA

Bjerring, Andrew K. \& St. Arnaud, Bill (2001): The Coming Revolution In Dark Fibre Networks: Can Canada be a World Leader in the next Internet Revolution? Canarie, Inc.http://vader.canet4.net/gigabit/gigabit.html

Canarie, Inc. (2001): Gigabit Internet to Every Canadian Home by 2005. Feb 18. http://vader.canet4.net/gigabit/gigabit.html

Canarie, Inc (2001a): Filling the Pipe: Stimulating Canada's Broadband Content Industry through $R \& D$. A fejlett szélessávú tartalommal foglalkozó nemzeti kerekasztalokról szóló jelentés. http://www.canarie.ca/press/publications.html

Canarie, Inc. (2002): Canet4, Canada's Research and Innovation Network. http://www.canarie.ca/canet4/index.html

Canarie, Inc. (2002a): [news] Remote gall bladder operation demonstrated over CA*net 4 CAnet-NEWS (Sat Nov 23 - 21:07:30 EST > archive $2002>$ search by date http://www.canarie.ca/canet4/library/list.html

Canarie, Inc. (2002b): Doing IT for the regions - Villages branchés du Québec. http://www.canarie.ca/press/publications.html

Canarie, Inc. (2002c): „A Nation Goes Online”: Canada's Internet History http://www.canarie.ca/press/publications.html

Canarie, Inc. (2002d): Shaping the future: Success stories from the CANARIE files. http://www.canarie.ca/press/publications.html

Cifra Médical, Inc. (2002): The Doctor is On-line. Az orvosok távoli helyekre sugárzásával a telegyógyászat jól használja ki az információs korszak által nyújtott nagysebességú hálózati alkalmazásokat. In Canarie, Inc. Shaping 
the future: Success stories from the CANARIE files, p. 7.

http://www.canarie.ca/press/publications.html

City of Kamloops, BC (2002): - Kamloops Community Network

http://www.city.kamloops.bc.ca/technology/cfn/index.html

City of Palo Alto, CA (2002): - FTTH (Fiber to the Home) Trial. http://www.cpau.com/fth

Cook Report (2002): The Future of the Industry. The Cook Report on Internet, XI, Nos. 1-2,

April-May, ISSN 1071-6327.

Cornell University (2002): The Broome-Tioga Boces Regional Telecommunication Infrastructure.

Abstract. Project report, draft, May 31. Draft Working paper prepared for the IEEE-USA Workshop On U.S. National Policy for Accelerating Broadband Deployment, Washington, D.C., June 17$18,2002$.

Cornell University (2002a): Case Study: SCT-BOCES Current Site of a Gigabit Ethernet over Fiber (GFE) Network. Abstract. Project report, draft, May 31. Draft Working paper prepared for the IEEE-USA Workshop On U.S. National Policy for Accelerating Broadband Deployment, Washington, D.C., June 17-18, 2002.

Denton, Timothy \& Ménard, François D. (2001): A Paradigm Shift for the Stupid Network: Interconnecting with Legacy Networks in the Internet Era. T.M. Denton, Consultants, Ottawa, Ontario, June 15. http://www.tmdenton.com

Dynamic City (2002): Case Studies: Grant County, WA. http://www.dynamiccity.com/grantcounty.htm

Finley, Gary (1999): The Alberta-wide CWDM Gigabit Ethernet for University \& Research Institutes. http://www.canarie.calconferences/adonet1999/index.html

FORBES ASAP (2001): Internet II: Rebooting America. September 10. Lead article by Malone, Michael S.; also Pizzo, Stephen P., Why is Broadband so Narrow;

McFadden, Daniel. The Tragedy of the Commons.

IEEE-USA (2002): The (R)evolutionary Telecommunications Paradigm of this Decade: Workshop Report. IEEE-USA Workshop On U.S. National Policy for Accelerating Broadband Deployment, Washington, D.C., June 17-18, 2002. (Final draft, approved December 2.)

IEEE-USA (2002a): Entity Statement: Accelerating Advanced Broadband Deployment in the US. December 23.

ITBusiness.ca (2002): Life science firms get into grids. Wednesday, June 12. $\mathrm{http}: / /$ www.itbusiness.ca

NETERA Alliance (2002): Alberta's research network gets \$1 million upgrade http://www.netera.ca/

Palo Alto Fiber Network (2002): Fiber To The Home. http://www.pafiber.net/

Poulton, Ken (1999): The Palo Alto Fiber to the Home Trial: A Work in Progress. http://www.canarie.ca/conferences/advnet 1999/index.html

Precursor Group (2002): The „insolvency Zone”: The Bankrupting of the U.S. Telecom Sector. Scott Cleland, May 20.

Proulx, Robert (1999): Costs and Process for Deployment of Dark Fibre Network. http://www.canarie.calconferences/advnet 1999/index.html

RISQ (2002): Réseau d'Études Scientifiques du Québec. Architecture of the Quebec Scientific Information Network.

Release 2.0, May 31. http://www.risq.qc.ca/reseau/index.php?LANG $=\mathrm{EN}$ 
Schweikhardt, Dennis (1999): Spokane School District No. 81: Gigabit Dark Fiber Network 19981999 Bond Project.

http://www.canarie.ca/conferences/advnet1999/index.html

SECOR (2001): Canadian School Board Investments in Private Fiber Optic Networks. Group Secor

Study, March. http://www.canarie.ca/canet4/library/customer.html

St. Arnaud, Bill (2000): Gigabit Internet to Every Canadian School by 2005. Canarie, Inc. http://www.canarie.ca/canet4/library/customer.html

St. Arnaud, Bill (2001): "Community Condo Fiber Networks”- The Customer Empowered Networking Revolution. Canarie, Inc. http://www.canarie.ca/canet4/library/customer.html

St. Arnaud, Bill (2001a): „eScience”: A new process of scientific discovery and innovation through Distributed Computing + Peer to Peer + Grids enabled by high-speed networks like Canet 4. Canarie, Inc. http://www.canarie.ca/canet4/library/general.html

St. Arnaud, Bill (2002): Frequently Asked Questions about Customer Owned Dark Fiber, Condominium Fiber, Community and Municipal Fiber Networks. Canarie, Inc. Last revised March 31. http://www.canarie.ca/canet4/library/customer.html

St. Arnaud,Bill (2002a): Wide Area and Long Haul Gigabit Ethernet:The LAN is invading the WAN. http://www.canarie.ca/canet4/library/general.html

St. Arnaud, Bill (2002b): The Third Wave. Canarie, Inc.

http://www.canarie.ca/canet4/library/general.html

World Wide Packets (2002): Municipalities And Public Utilities Gather To Learn About Broadband Deployment At World Wide Packets Sponsored Conference. Spokane, WA - July 8. Community-wide broadband deployment. http://www.wwp.com/news/newsReleases_2002.jsp

\section{Európa}

ESIS (1999): Alternative Networks in EU Member States. Last updated Jan 1, 1999. http://www.eu-esis.org/Alternative/HomeAlterQ8.htm. A weboldalon országonkénti jellemzést találhatunk. A Synoptic Tables letölthetố ugyanerrôl a weboldalról ANTAB9901.pdf néven.

ESIS (2002): ESIS Knoweledge Base: An ISPO Information Service. http://wrw.eu-esis.org/script/form_simple.cgi. A projektek összegzése.

European Union, Commission of the European Communities (2002): eEurope 2005: An information society for all. An Action Plan to be presented in view of the Sevilla European Council, 21/22 June 2002. Communication From The Commission To The Council, The European Parliament, The Economic And Social Committee And The Committee Of The Regions. Brussels, 28 May. COM(2002) 263 final http://www.europa.eu.int [eeurope2005_en.pdf]

McKinsey (2002): A Dark Fibre Paradise: Interview with Jonas Bergersson. (Sweden, fibre) http://www.mckinsey.de/_downloads/knowmatters/telecommunications/bro adband_dark.pdf

Netnod (2002): Existing and Planned Internet Exchange Points in Sweden. http://www.netnod.se/existing.htm

OECD (2001): The Development of Broadband Access in OECD Countries. Directorate for Science, Technology, and Industry - Committee for Information, Computer, and 
Communication Policy - Working Party on Telecommunication and

Information Service Policies, 29 October. http://www.oecd.org > directorates

$>$ Science, Technology, and Industry $>$ Information and Communications

Policy $>$ Telecommunications and Internet Policy $>$ Search

Stockholm Stad (2000): Agenda for the City of Stockholm Briefing at CANARIE's Workshop on Gigabit to the School. Canarie, Inc., 1999 Workshop. Canarie, Inc., Index of /press/publications/pdf/workshop99, May 25. Roos.pdf a http://www.canarie.ca/press/publications/pdf/workshop99/ címen.

Swedish ICT Commission (2000): A Proposal for a National Communications Infrastructure in Sweden: 2000-2030. Az írást kiadta: Swedish ICT Commission at Canarie, Inc 1999 Workshop. http://www.canarie.ca/conferences/advnet1999/index.html. Kattintson Peter Lothberg elóadására, hogy letölthesse a lothberg.pdf -et.

Swedish ICT commission (2001): General Guide to a Future Proof IT infrastructure. Guidebook for municipal/community fiber networks. Bizonyos mértékig leírja, hogyan tudják telepíteni a közösségek és a városok a nyílt hozzáférésú alépítményeket és a sötét optikai kábelt alacsony költségú információs technológia kiépítéséhez. Általános útmutató az optikai kábelek telepítésének elsố lépéseihez.

http://www.itkommissionen.se/extra/document/?id=347

TERENA (2002): TERENA NREN Compendium 2002, AnalyticalPpart. Trans-European

Research and Education Networking Association, http://www.terena.nl/compendium/2002/

\section{Teleházak}

BEEP (2002): Telecottages to serve the local community (Hungary). Better e-Europe Practices. http://beep.server55.jepponet.dk/Search/ShowCaseFullReport.asp?CaseID=504

Gryderman, Kelly (1999): Latin American Telecentres: The Community Networking Pilot Project.

IDRC Reports,

http://www.idrc.ca/reports/read_article_english.cfm?article_num $=347$

Demnet (2002): Establishment of Telecottages in Yugoslavia. http://www.demnet.org.hu/e_pastprog/yugo.doc.

Demnet (2002): Foundation for the Development of Democratic Rights. See „Current Programs” and „Past Programs.” http://www.demnet.org.hu/index_english.html

Gamucio Dagrón, Alfonso (2001): Prometheus Riding in a Cadillac? Telecenters as the Promised Flame of Knowledge. The Journal of Development Communications

(Kuala Lumpur, Malaysia) Vol 12 No 2, December, 85-93.

Gáspár, Mátyás (2001): Telecottage-The chance for small communities to develop. In: Foundation for the Development of Democratic Rights (FDDR) Telecottages in Yugoslavia, 13-32; DemNet Series No. 5, Paktum Bt., Budapest, Hungary, ISBN 9630097346

Gáspár, Mátyás (2001a): Telehouses in Hungary. The Journal of Development Communications (Kuala Lumpur, Malaysia) Vol 12 No 2, December, 60-70.

IDRC Telecentre Research http://www.idrc.ca/pan/telecentres.html 
ITU (1998): Integrated Rural Development and Universal Access: Towards a Framework for

Evaluation of Multipurpose Community Telecentre, Pilot Projects Implemented by ITU and its Partners. Johan Emberg. Ontario, Canada: International Telecommunications Union, October.

http://www.itu.int/ITU-D/univ_access/telecentres/papers/guelph.html

ITU (2001): Telecentres in Hungary. International Telecommunication Union.

http://www.itu.int/ITU-D/univ_access/casestudies/hun_mct.html.

Koranyi, Balazs (2002): „Hungary's Telecottages Introduce the Internet for a Welcome Stay.” The Wall Street Journal, August 7, p. B8C.

Larsson, Mimi (2002): On Myths and Misunderstandings about Hungarian Telecottages. The Information Society and Trend Research Institute, Technical University of Budapest, Hungary.

Latchem, Colin \& Walker, David, eds. (2001): Perspectives on Distance Education - Case Studies and Key Issues. Vancouver, Canada, The Commonwealth of Learning. (COL) A tanulmány ingyenesen letölthető a http://www.col.org/Telecentres/ címrôl; [COL 01 Telecentres]

OECD (2001a): Information and Communication Technologies and Rural Development. OECD

ICT\&Ruraldev 0401081E.PDF http://www.oecd.org

Short, Gail (2001): Lessons Learned in Pioneering Telecenters in Australia. The Journal of Development Communication (Kuala Lumpur, Malaysia) Vol 12 No 2, December, 39-46.

The Journal of Development Communication (2001): Telecenters and ICT for Development. Special issue, Vol. 12, No 2, December. Kuala Lumpur, Malaysia.

UNESCO (2001): Digital Opportunities for Central and Eastern Europe Community Multimedia Centres, Background Paper, Bucharest, Romania, December. http://www.unesco.org/webworld/com/cmc/ > klikkeljen a background_paper.pdf-re.

Whyte. Anne (2000): Assessing Community Telecentres: Guidelines for Researchers. (for the Acacia Initiative of IDRC) ISBN 0-88936-916-X, 120 pp. Letölthető:

http://www.idrc.ca/acb/showdetl.cfm?\&DID $=6 \&$ Product_ID $=520 \& \mathrm{CA}$ $\mathrm{TID}=15$ 